Saša Kovačević Mihael Golubić

Saša Kovačević Institut za arheologiju sasa.kovacevic@iarh.hr

Mihael Golubić Hrvatski restauratorski zavod Odjel za restauriranje arheoloških nalaza mgolubic@hrz.hr

Stručni rad / Professional paper

Primljen / Received: 10. 7. 2020.

DOI: http://doi.org/10.17018/portal.2020.1

UDK: 7.025.4:[903.5(497.5 Jalžabet)"638"

\section{Restauriranje nalaza halštatskog razdoblja iz tumula u Jalžabetu}

SAŽEtaK: U Jalžabetu u Podravini jugoistočno od Varaždina nalazi se jedan od najvažnijih krajolika starijega željeznog doba u Republici Hrvatskoj. Arheološka istraživanja počela su na tom lokalitetu sondiranjima još šezdesetih godina prošloga stoljeća, a ponovo su intenzivirana tijekom provedbe projekta „Monumentalni krajolici starijega željeznog doba Podunavlja“" ("Iron-Age-Danube” Interreg DTP 2017. - 2019.) i zaštitnim arheološkim istraživanjima monumentalnog grobnog humka Gomile od 2017. do 2019. godine. Usporedno s novim interdisciplinarnim i arheološkim istraživanjima počela je sustavna obrada građe iz ranijih istraživanja. Tako su u radionici Odjela za restauriranje arheoloških nalaza Hrvatskog restauratorskog zavoda postupno restaurirani koštani i metalni nalazi iz tumula 2, a istodobno se počelo i s konzerviranjem i restauriranjem novih nalaza pronađenih $u$ istraživanjima $u$ protekle tri godine. $U$ tekstu se daje pregled rezultata dosadašnjih arheoloških istraživanja $u$ Jalžabetu te se predstavljaju postupci konzerviranja i restauriranja pokretnih arheoloških nalaza iz starijega željeznog doba pronađenih u Jalžabetu.

KLJUČNE RIJEČI: Jalžabet, Podravina, središnja Hrvatska, starije željezno doba, halštatsko razdoblje, kneževski grobovi, pokretni arheološki nalazi, konzerviranje, restauriranje
$\mathrm{N}$ a neki način, Jalžabet je generacijama mladih arheologa bio svojevrsna „zlatna jabuka“. Zanimanju za daleku prošlost Jalžabeta, ali i za arheologiju starijega željeznog doba znatno su pridonijela arheološka istraživanja tumula 2, provedena 1989. godine, a proveli su ih Marina Šimek i zaposlenici Gradskog muzeja Varaždin. Iznimni rezultati tih istraživanja u Jalžabetu izazvali su veliko zanimanje u cijelom arheološkom svijetu i potaknuli Institut za arheologiju da se nakon višedesetljetne stanke, nakon pomnog planiranja, vrati istraživanjima halštatske kulture u slijevu Plitvice i Bednje. ${ }^{1}$ Godine 1997. plato na vrhu nije se još obrađivao i tumul je polako preuzimala visoka trava i nisko grmlje. ${ }^{2}$ Nitko tada, a ni poslije, nije planirao voditi arheološka istraživanja jalžabetske Gomile. Dvadeset godina kasnije, nakon otkrića pljačke i devastacije Gomile, 2017. godine počela su zaštitna arheološka istraživanja. Kompleksna istraživanja toga gigantskog tumula (teško oštećenog u pljački) financiralo je Ministarstvo kulture Republike Hrvatske. U trenutku pisanja ovoga teksta istraživanja nisu sasvim dovršena. Usporedno s novim interdisciplinarnim i arheološkim istraživanjima počela je sustavna obrada građe iz starijih istraživanja. U Odjelu za restauriranje arheoloških nalaza Hrvatskog restauratorskog 


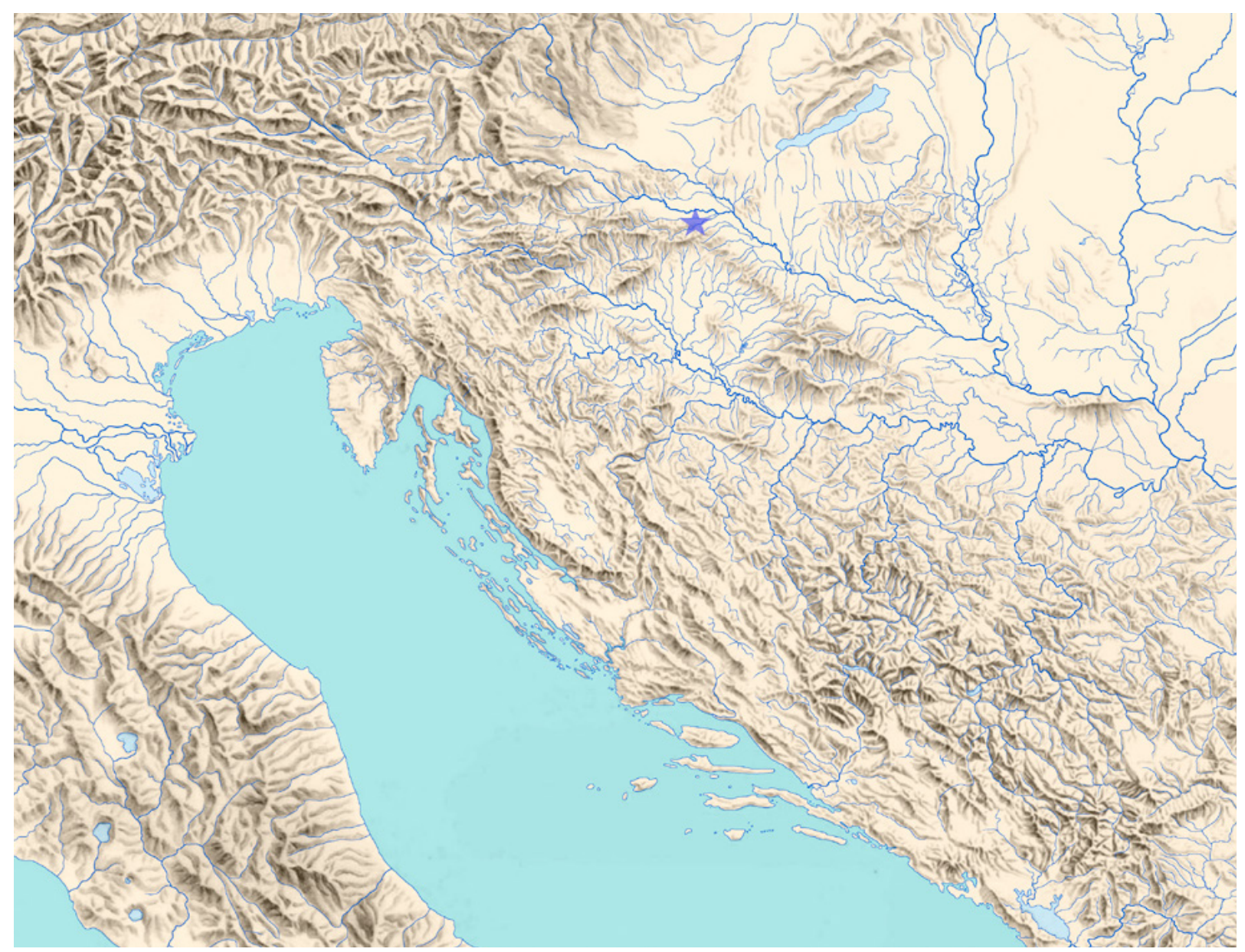

1. Položaj Jalžabeta u širem geografskom kontekstu (IA)

Location of Jalžabet in a broader geographical context (IA)

zavoda postupno su restaurirani koštani i metalni nalazi iz tumula 2, uz istovremene radove na konzerviranju i restauriranju novih nalaza iz Gomile, pronađenih $u$ istraživanjima u protekle tri godine. Uz to, provedene su i prve interdisciplinarne analize uzoraka i nalaza iz Jalžabeta na Šumarskom fakultetu Sveučilišta u Zagrebu, na Katedri za biofiziku Medicinskog fakulteta Sveučilišta u Zagrebu, Zavodu za paleontologiju i geologiju kvartara HAZU-a te na Institutu za fiziku i Institutu za antropologiju iz Zagreba. ${ }^{3}$ Dok se pisao ovaj tekst, dio slikanih koštanih predmeta iz Jalžabeta poslan je na analizu u briselski Royal Institute for Cultural Heritage (KIK-IRPA). Osim toga, i druge analize su još u tijeku pa će biti objavljene $\mathrm{u}$ drugoj publikaciji. ${ }^{4} \mathrm{U}$ tekstu se daje pregled rezultata dosadašnjih arheoloških istraživanja u Jalžabetu te se predstavljaju postupci konzerviranja i restauriranja pokretnih arheoloških nalaza iz starijega željeznog doba pronađenih u Jalžabetu.

\section{Položaj lokaliteta}

Jalžabet, malo mjesto petnaestak kilometara jugoistočno od Varaždina, danas je središte općine koju geografski umnogome određuje rijeka Drava na sjeveru te pobrđe na jugu. Upravo uz sam južni rub dravske ravnice, oko dva kilometra istočno od središta Jalžabeta, s desne strane ceste Jalžabet - Ludbreg, smjestio se drevni kulturni krajolik. Nizinskim, blago valovitim područjem teče potok Bistričak, a dominira Gomila, jedan od najvećih grobnih humaka u ovom dijelu Europe (sl. 1 i 2). Bistričak izvire $u$ brdima $u$ zaleđu Jalžabeta, a $u$ nizinskom kraju sjeverozapadno od Gomile ulijeva se u Plitvicu. Rijeka Plitvica, koja u tom dijelu svojega toka krivuda usporedno s Dravom, u veliku se rijeku ulijeva u Malom Bukovcu, sjeveroistočno od Ludbrega. Uz rijeku Savu, upravo zlatonosna Drava kroz cijelu je prošlost jedna od ključnih poveznica alpskoga prostora na zapadu i Podunavlja na istoku. ${ }^{5}$ Naselje starijega željeznog doba nalazi se u blizini, preko potoka, na položaju Carev jarek. Nakon geofizičkih istraživanja provedenih 2016. godine, postojanje naselja halštatske kulture na lijevoj obali Bistričaka potvrđeno je arheološkim istraživanjima 2017. godine. ${ }^{6}$ Potok koji teče između naselja i nekropole nije samo magična linija koja dijeli svijet živih na jednoj obali od svijeta mrtvih na drugoj, nego je morao biti među ključnim resursima za život ljudi u obližnjem naselju starijega željeznog doba. U njemu treba vidjeti izvor pitke vode, moguće i hrane, za 


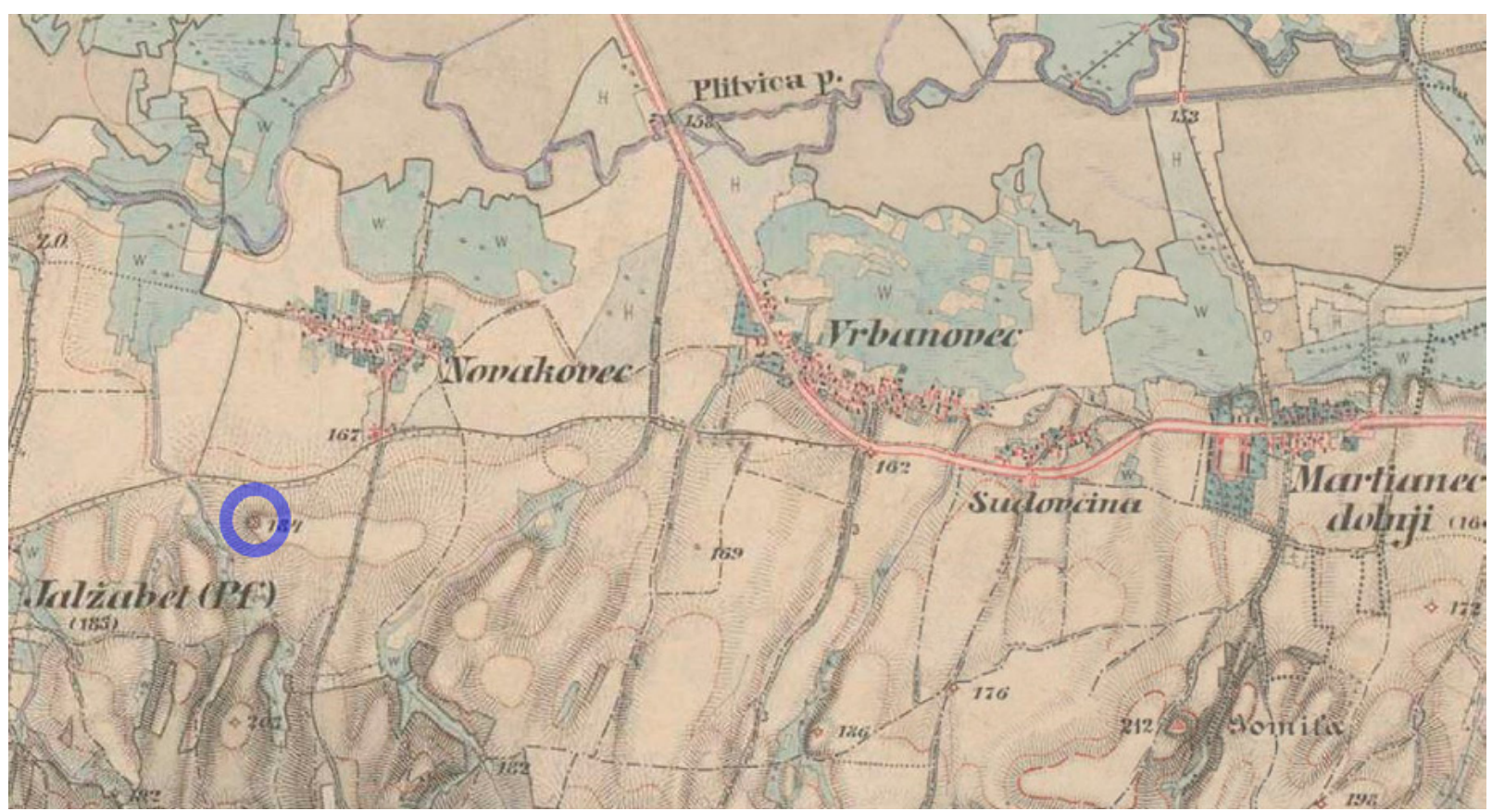

2. Položaj Gomile na vojnoj karti iz 19. stoljeća (preuzeto s www.mapire.eu, 18. 11. 2020.)

Location of Gomila on a military map from the $19^{\text {th }}$ century (www.mapire.eu)

stanovnike naselja, ali se iz njegova korita mogla eksploatirati glina ili oblutci. Oba materijala obilno su korištena i pri gradnji tumula $u$ Jalžabetu. ${ }^{7}$ Iako potok Bistričak nije mogao biti jedini izvor velikih količina oblutaka korištenih za gradnju obaju jalžabetskih tumula, prikladni izvor toga materijala u blizini nije mogao biti ignoriran. Zahvaljujući preliminarnim analizama geoloških karata, saznajemo da se ležišta sitnijeg šljunka nalaze, kao i naslage pješčenjaka, u pobrđu južno od Jalžabeta. ${ }^{8}$ Analiza snimke LiDARom, izvedene u sklopu projekta Interreg DTP „Iron-Age-Danube“, izdvojila je nekoliko zanimljivih položaja južno od Gomile, moguće i područja eksploatacije kamenog materijala. ${ }^{9}$

\section{Povijest istraživanja}

Da je Gomila u Jalžabetu mjesto od posebne važnosti, vjerojatno su oduvijek znali ljudi koji su živjeli u njezinoj sjeni. Svijest o tome i danas se jasno provlači u nekoliko varijanti lokalnih legendi vezanih uz jalžabetski gigantski tumul, kao i povremena pojava "gomile“ ili „mogile“ $u$ novinskim izdanjima. ${ }^{10}$ Kao što je poznato, to je jedan od najvećih prapovijesnih grobnih humaka u srednjoj Europi, promjera oko $65 \mathrm{~m}$, sačuvane visine oko $8 \mathrm{~m}$. Istraživači će se za područje južno od Drave i cijeli varaždinski kraj vrlo rano zainteresirati. Matija Petar Katančić, Ivan Kukuljević Sakcinski, poslije Šime Ljubić, Josip Brunšmid i Đuro Szabo samo su neka od velikih imena koja su se bavila temama iz prošlosti sjeverozapadne Hrvatske još od kraja 18. stoljeća. Prije, tijekom i nakon Drugoga svjetskog rata posebno je važna djelatnost Stjepana Vukovića, seoskog učitelja i inovativnog prvog kustosa Prehistorijskog odjela
Gradskog muzeja Varaždin, osnovanog 1949. godine. ${ }^{11}$ Nakon Drugoga svjetskog rata, područja uz rijeku Dravu postat će redovito odredište i supružnika Zdenka Vinskog i Ksenije Vinski-Gasparini iz Arheološkog muzeja u Zagrebu. Oni će prikupljati nalaze, obilaziti lokalitete, bilježiti uočene grobne gomile, ali i provoditi arheološka istraživanja. Upravo istraživanja tumula Gamulice u Martijancu, oko pet kilometara istočno od Jalžabeta, ishodišna su točka za razumijevanje halštatske kulture na sjeveru Hrvatske. ${ }^{12}$ Ksenija Vinski-Gasparini sondirala je 1963. godine i veliki tumul - Gomilu u Jalžabetu ${ }^{13}$

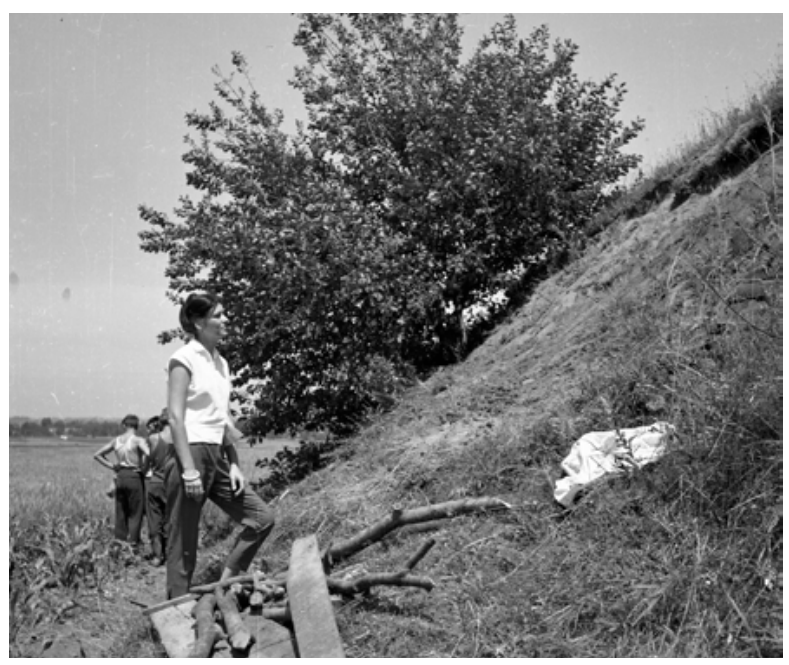

3. Ksenija Vinski-Gasparini tijekom sondiranja Gomile u Jalžabetu 1963. (arhiva AMZ-a, 011_JLZ_1963-0029)

Ksenija Vinski-Gasparini during field surveying of Gomila in Jalžabet in 1963 (AMZ Archive, 011_JLZ_1963-0029) 


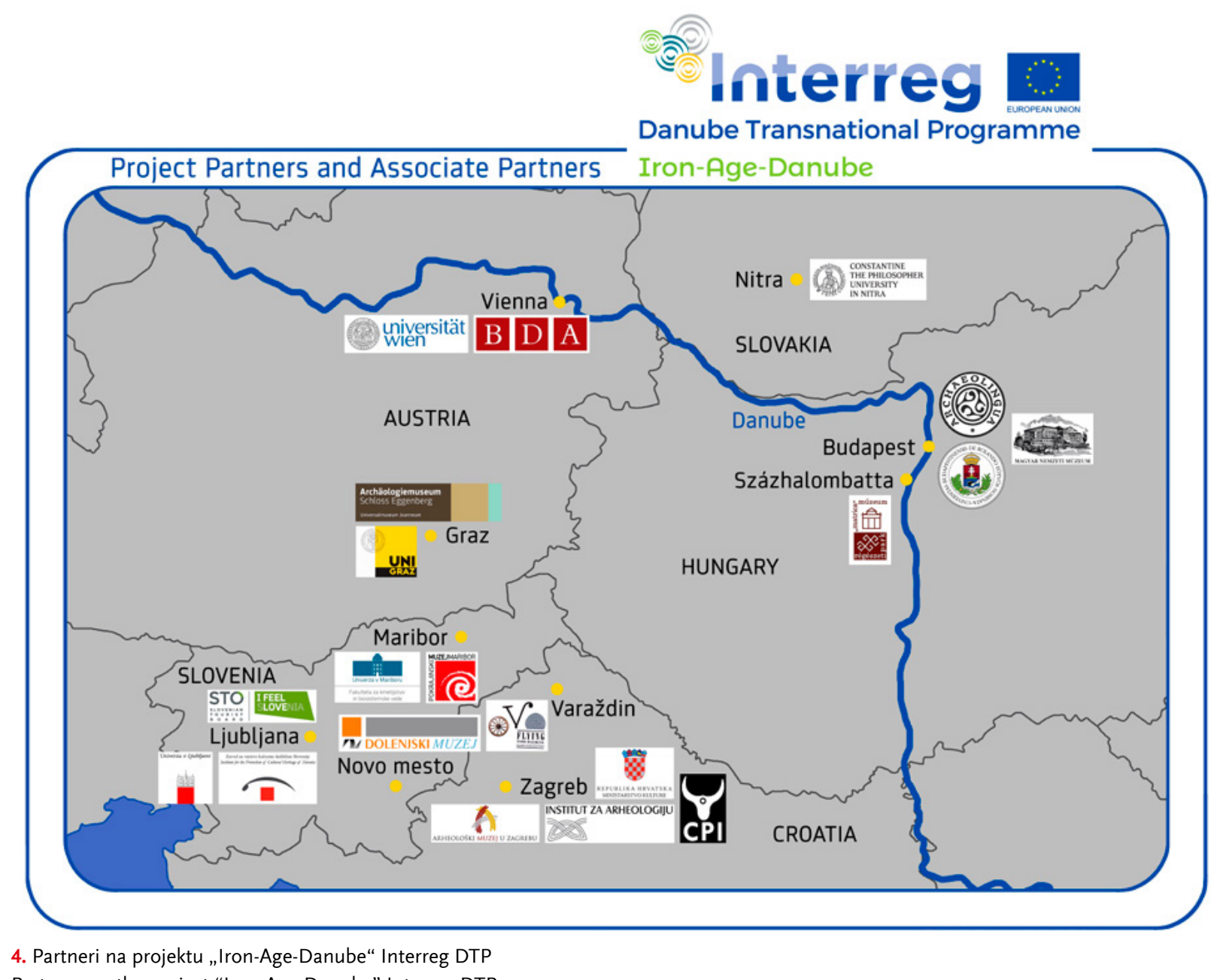

Partners on the project "Iron-Age-Danube" Interreg DTP

(sl. 3), postavivši po jednu malu sondu na zapadnu i istočnu padinu tumula. ${ }^{14} \mathrm{U}$ istočnoj sondi pronašla je nekoliko fragmenata keramike koja prema fakturi pripada starijem željeznom dobu, a na dubini od dva metra došla do konstrukcije od kamenih oblutaka. Tu je, zbog nedostatka financijskih sredstava, istraživanja morala zaustaviti. ${ }^{15}$ Podaci s tih probnih istraživanja desetljećima će ostati jedine dragocjene informacije o velikom tumulu u Jalžabetu.

Kao ilustracija da je područje Jalžabeta i u kasnijim razdobljima igralo važnu ulogu, služe nam ostaci rimske vile, ceste te kamenog mosta preko Plitvice, koje je zabilježio Stjepan Vuković. ${ }^{16}$ Ti nalazi indiciraju da je u Jalžabetu u rimsko vrijeme bio važan prijelaz preko rijeke Plitvice i sjecište putova prema Ludbregu i Varaždinskim Toplicama. Poznata je činjenica da rimske ceste često slijede prapovijesne prometne pravce, pa je taj prometni krak, koji se u smjeru juga odvaja od glavnoga longitudinalnog pravca uz rijeku Dravu (Petovio - Mursa), vjerojatno vrlo stara transverzalna komunikacija. Isprepletenost manjih vodotokova i blizina Drave (kao važnog prometnog puta koji se u prošlosti nastavljao na „jantarni put“ te povezivao istočne Alpe s krajevima na istoku Karpatske kotline) morali su imati znatnu ulogu u profiliranju područja Jalžabeta i Martijanca kao važnog središta naseljenosti tijekom halštatskog razdoblja, ali i poslije. Upravo položaj utvrđene rimske vile uz Plitvicu, nekoliko kilometara zračne linije od Gomile prema sjeverozapadu, šezdesetih godina prošloga stoljeća arheološki istražuje druga arheologinja Arheološkog muzeja u Zagrebu, Branka Vikić-Belančić. ${ }^{17}$ Nakon više desetljeća, u Jalžabetu se ponovo istražuje 1989. godine. Prilikom jednog od brojnih rekognosciranja Jalžabeta i okolice, djelatnici Gradskog muzeja u Varaždinu uočili su s vrha Gomile veću količinu izoranih vapnenačkih ploča i na taj način ubicirali do tada nepoznatu grobnicu. Marina Šimek iz Gradskog muzeja u Varaždinu potpuno je istražila taj grobni humak - tumul $2 .{ }^{18}$ Hitnim zaštitnim arheološkim istraživanjima 1989. godine obuhvaćen je središnji dio do neprepoznatljivosti snižene grobne gomile, stotinjak metara istočno od gigantskoga tumula Gomile. Iako je tumul gotovo do kraja bio snižen poljoprivredom, konstrukcija kameno-drvene grobne komore s dromosom na istočnoj strani i nizom pokretnih nalaza iznimno je važan skup podataka o vremenu kad se na širem području događaju velike promjene u razvoju i materijalnoj kulturi starijega željeznog doba. S druge 


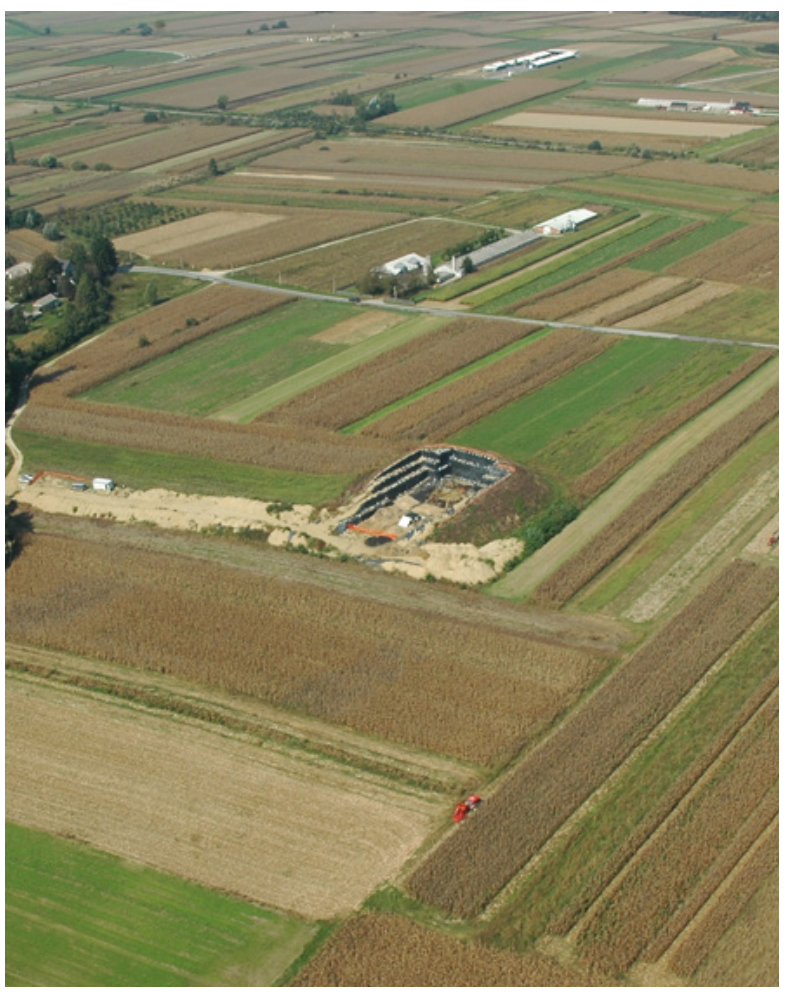

5. Zračna fotografija Gomile u Jalžabetu tijekom zaštitnih istraživanja 2018. (snimili M. Šimek i T. Trubić, 2018.) Aerial photographs of Gomila in Jalžabet during protective excavations in 2018 (M. Šimek, T. Trubić, 2018)

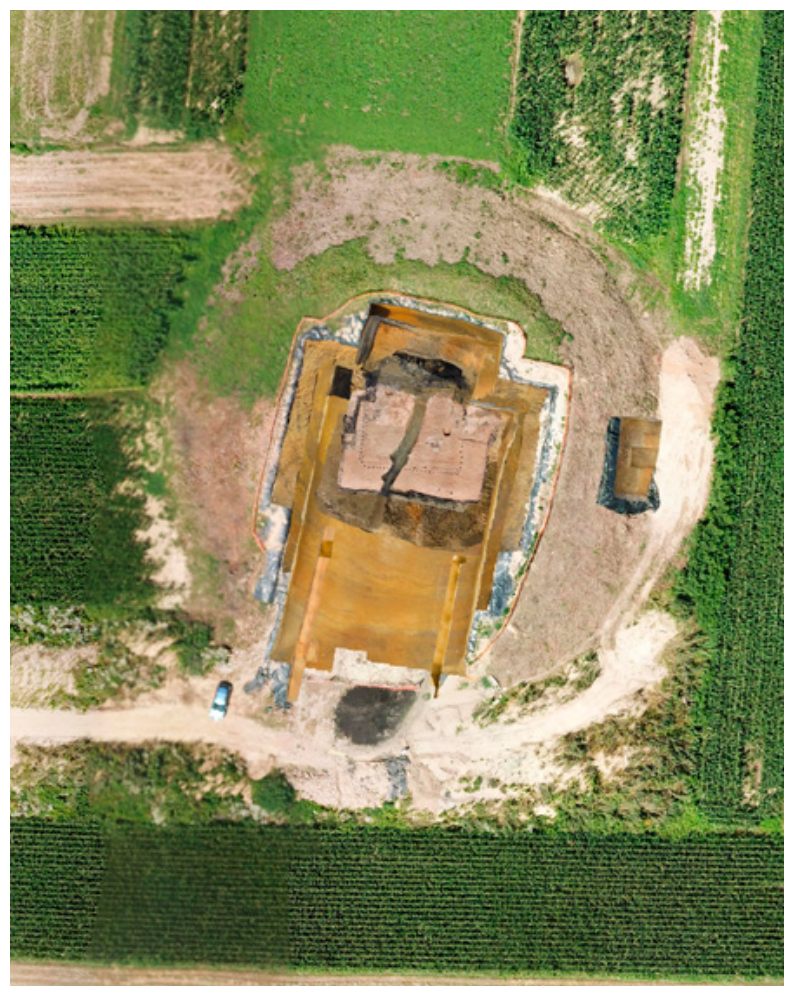

6. Fotogrametrijski prikaz arheoloških istraživanja grobne komore tumula 1 - Gomile u Jalžabetu, s položajem sonde 2 na istočnoj padini (izradio M. Mađerić, 2019.)

Photogrammetric presentation of archaeological excavations of the tomb chamber in tumulus 1, Gomila, in Jalžabet, with the position of probe 2 on the eastern slope (M. Mađerić, 2019)

unija. ${ }^{22} \mathrm{U}$ tom projektu sudjelovalo je dvanaest partnerskih ustanova iz pet srednjoeuropskih zemalja, s vodećim partnerom Universalmuseum Joanneum iz Graza (sl. 4). Pridruženi partneri Instituta za arheologiju (PP6) bili su Ministarstvo kulture Republike Hrvatske (ASP5) i Turistička zajednica Varaždinske županije (ASP7). Okosnica projekta bila je istraživanje, očuvanje i održivo korištenje najvažnijih krajolika starijega željeznog doba srednje Europe. Upravo dobro poznat krajolik starijega željeznog doba u Jalžabetu (PP6) izabran je kao jedan od dvaju središta projektnih aktivnosti u Republici Hrvatskoj. ${ }^{23}$ Drugu žarišnu točku projektnih aktivnosti u Republici Hrvatskoj činili su arheološki lokaliteti i krajolik starijega željeznog doba na sjeveru Požeške kotline (PP7), Arheološki muzej u Zagrebu). Projektna pravila omogućila su ekstenzivna geofizička istraživanja, snimanje jalžabetske mikroregije LiDAR-om i probna arheološka istraživanja, kao dopuna saznanja o arheološkim krajolicima. ${ }^{24}$ Arheološka iskopavanja 2017. godine u Jalžabetu otkrila su više novih podataka. Otkriće dotad nepoznatog naselja iz rane faze brončanog doba na Bistričaku, definiranje segmenata golemog cirkularnog kanala oko Gomile te prve potvrde prisutnosti Rimljana u sjeni velikog tumula, neki su od najvažnijih rezultata arheoloških istraživanja u sklopu Kampa Hrvatska, projekta „Iron-Age-Danube” u 2017. -Danube” Interreg DTP), koji je sufinancirala Europska 


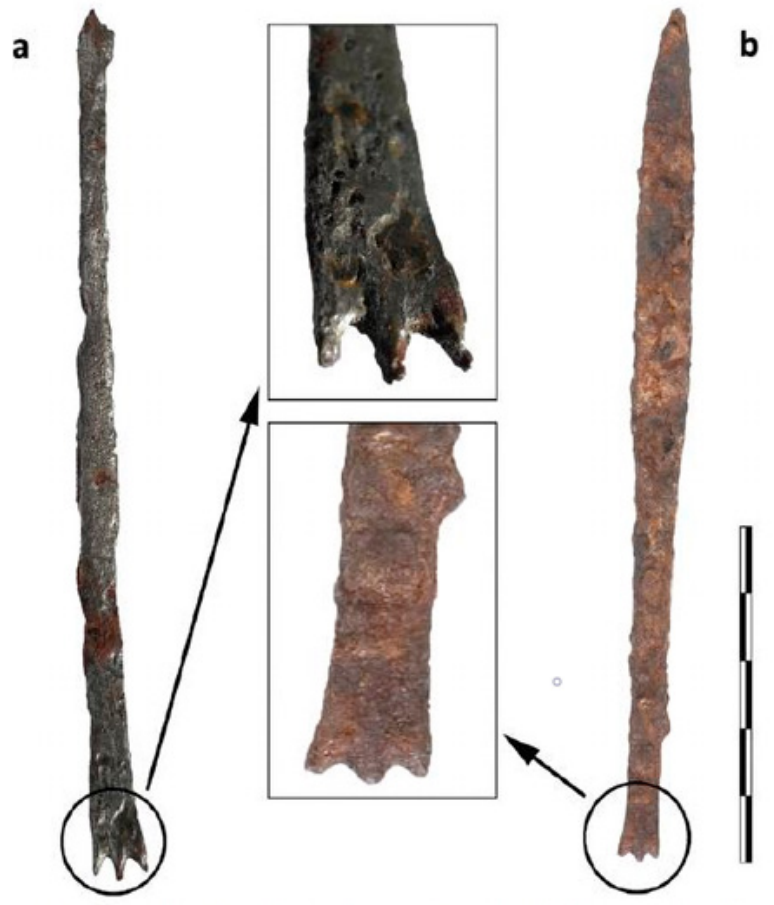

7. Dvije alatke za ukrašavanje predmeta od roga iz Caričina grada (NEMANJA MARKOVIĆ, SONJA STAMENKOVIĆ, 2016.)

Two tools for decorating horn objects from the Empress's City (NEMANJA MARKOVIĆ, SONJA STAMENKOVIĆ, 2016)

godini. ${ }^{25} \mathrm{~S}$ druge strane, projekt je činio niz intenzivnih promotivno-edukacijskih i popularno-znanstvenih aktivnosti kojima je osnovna svrha bila senzibilizirati što više ljudi za probleme iznimno osjetljive prapovijesne arheološke kulturne baštine. Održan je niz seminara, okruglih stolova, predavanja i školskih radionica u Varaždinu, Jalžabetu i drugim mjestima, a na razini projekta izrađene su i Strategije za monumentalne (pra)povijesne krajolike Podunavlja te baza podataka s lokalitetima starijega željeznog doba (Strategies for monumentalized (pre) historic landscapes in the Danube Region https://www.iron-age-danube.eu/). Postavljanjem arheološko-turističke staze u Jalžabetu 2019. godine, počela je prezentacija toga iznimnog arheološkog krajolika. ${ }^{26}$ Nažalost, ujesen 2017 . godine, usred provedbe projekta Iron-Age-Danube otkriveno je da je gigantski tumul 1 - Gomila u Jalžabetu opljačkan i teško oštećen. Taj je događaj bio pokretač zaštitnih istraživanja koja je financiralo Ministarstvo kulture Republike Hrvatske, koja su se nastavila 2018. i 2019. godine (sl. 5 i 6). Pokretni arheološki nalazi, osobito monumentalna grobna arhitektura, i kompleksni pogrebni ritual potvrđuju da je Gomila jedan od najvažnijih prapovijesnih spomenika te vrste istraženih u posljednje vrijeme $u$ Europi. U tekstu ćemo predstaviti zahtjevno konzerviranje i restauriranje izabranih pokretnih arheoloških nalaza iz Jalžabeta i tako dati prilog raspravi o izgledu i funkciji predstavljenih nalaza.

Tijekom istraživanja posljednjih nekoliko godina sasvim su izmijenjena i u velikoj mjeri dopunjena naša saznanja o arheološkom profilu Jalžabeta, ali i o samoj Gomili. Otkrili smo da je u izvornom obliku Gomila imala sasvim drugačiji izgled te je njezino stanje prije početka zaštitnih istraživanja zapravo izravna posljedica antropogenog djelovanja tijekom 2600 godina. Naime, plato na vrhu tumula i njegov izgled krnjeg stošca nije izvorni oblik tumula nakon završetka gradnje u starijem željeznom dobu. ${ }^{27}$ Ispod Gomile nalazila se kvadratna grobna komora veličine 12 x 12 metara. Na komoru se s istočne strane nastavljao masivni dromos. Osnovni građevinski materijal činili su drvo, glina, oblutci, pješčenjak i vapnenac. Komora se nalazila na krepidi, podestu od kamena, promjera oko trideset metara, koji je jasno ograničen lijepo posloženim suhozidnim vijencem od velikih kamenih ploča. U strukturi grobne komore možemo prepoznati faze planiranja i izvedbe, odnosno gradnje koje su isprepletene s nizom kompleksnih ritualnih radnji. Oblutci i siva glina te velike količine spaljenog drva pokrivali su kompozitno građene zidove komore s vanjske strane. ${ }^{28}$ Unutrašnjost grobne komore bila je popločena kalanim pločama pješčenjaka i pokrivena drvenom oplatom. Uz južni zid komore, na popločenju poda, pronašli smo debeo sloj spaljenih kostiju; pod težinom urušenog pokrova komore sloj s kostima je u dva i pol tisućljeća komprimiran. U radnoj hipotezi te su kosti ostaci više spaljenih životinja, ali i ostaci preminule osobe sa samog vrha halštatskog društva Jalžabeta i regije, one za koju je cijela monumentalna konstrukcija kompleksne grobnice i izgrađena. ${ }^{29}$ Velike količine koštanog materijala iz Gomile bit će podvrgnute antropološkim i zooarheološkim analizama. One bi trebale izolirati i analizirati potencijalne ostatke čovjeka te pojedinih životinjskih vrsta i tako pomoći rasvijetliti problematiku ukopa pod tumulima tijekom starijega željeznog doba u dolini rijeke Drave.

\section{Kulturno-kronološka atribucija nalaza iz Jalžabeta}

Iako smo od detaljne analize pronađenog još daleko, a arheološka istraživanja u trenutku pisanja ovoga teksta nisu ni završila, možemo potvrditi da su nalazi iz Gomile kronološki i kulturno srodni onima iz tumula 2 u Jalžabetu. Dio nalaza, poput brončanih dijelova garniture konjske opreme, praktički je identičan onima iz tumula $2 .^{30}$ Relativnokronološki, pripada stupnju Ha D1, okvirno prvoj polovici 6. stoljeća pr. Kr., završnom horizontu grupe Martijanec - Kaptol ili stupnju Štajerska III. ${ }^{31}$ Prije detaljnog restauriranja i analize pokretnih nalaza, možemo pretpostaviti da Gomila pripada istom vremenu kao i glasoviti istovremeni tumuli iz Kleinkleina, Strettwega ili Kaptola. ${ }^{32}$ Nalazi iz tumula 2, ali i novootkriveni nalazi iz Gomile, često su bili oštećeni u vatri. Brojni (bez sumnje luksuzni) predmeti od bronce, željeza, kosti i drva deformirani su u različitom stupnju ili sasvim uništeni. Dijelove kojih predmeta su izvorno činile u Gomili nađene velike količine rastaljenih amorfnih grumena bronce, vjerojatno nikad 

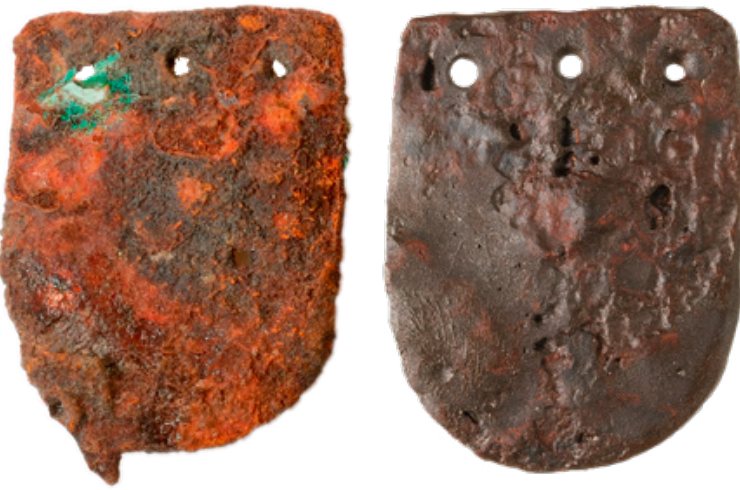

8. Željezna ljuska oklopa, stanje prije (lijevo) i nakon radova (desno). Dimenzije: 30 x 23 mm (fototeka HRZ-a, snimio J. Škudar, 2018.)

Iron armour scale, condition before (left) and after (right) conservation. Dimensions: 30 × 23 mm (HRZ Photo Archive; J. Škudar, 2018)

nećemo saznati. No dio nalaza tek je dodirnut vatrom ili uopće nije gorio, što iznova upućuje na kompleksne rituale koji su se događali na Bistričaku. Ofenzivno i defenzivno oružje, konjska oprema, nakit od jantara i kosti, posuđe od keramike i bronce zasjat će nakon dugotrajnog i složenog postupka restauriranja. Urezivanjem i slikanjem lijepo ukrašeni koštani predmeti pojavljuju se i u tumulu 2 i u Gomili. Pretpostavljamo da su služili kao intarzije na većim predmetima od drva ili su ulomci manjih utilitarnih predmeta, poput cilindričnih posudica ili ručki. Metodologija izrade i koncept ukrasa iz obaju tumula, barem na prvi pogled, čine se vrlo sličnima. Prve znanstvene analize na Institutu za fiziku te Katedri za biofiziku Medicinskog fakulteta $u$ Zagrebu pokazale su da su urezani motivi na koštanim trokutima iz Gomile i na koštanim strelicama iz tumula $2 \mathrm{u}$ Jalžabetu ispunjeni crnim pigmentom istoga kemijskog sastava. ${ }^{33}$ Nizovi urezanih kružića i linija bit će omiljeni motiv na predmetima od kosti ili roga, ali i metala i na drugim lokalitetima starijega željeznog doba, kao i u kasnijim vremenima. ${ }^{34}$ Posebno se zanimljivom čini trozuba alatka iz radionice predmeta od roga iz Caričina grada iz vremena Justinijana, iz 6. stoljeća n. Kr. ${ }^{35}$ Takvu jednostavnu željeznu alatku (sl. 7) nije teško zamisliti ni u uporabi 1200 godina prije, u nepoznatoj radionici, možda unutar halštatskog naselja na Carevu jarku u Jalžabetu.

\section{Konzerviranje i restauriranje metalnih $\mathrm{i}$ koštanih nalaza iz tumula 2}

Istodobno s novim arheološkim istraživanjima Gomile u Jalžabetu počela je i sustavna obrada građe iz starijih istraživanja sa susjednog lokaliteta Jalžabet - tumul 2. Zaprimljeni su i brojni predmeti s Gomile, čije je restauriranje $u$ tijeku ili će biti provedeno sljedećih godina. Konzervatorsko-restauratorska obrada provodi se $u$ radionici Odjela za restauriranje arheoloških nalaza Hrvatskog
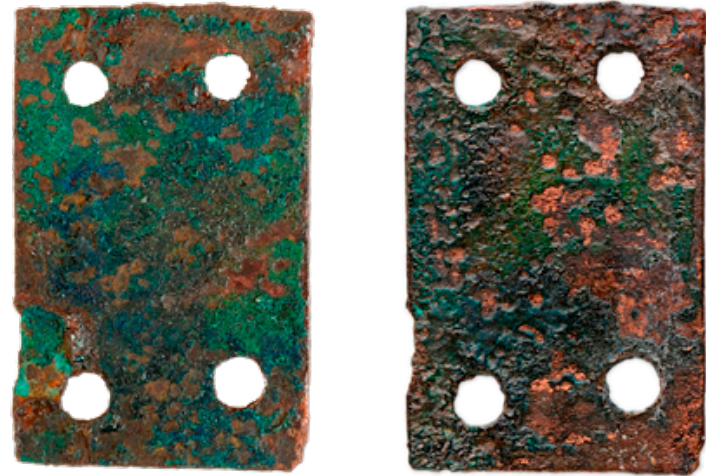

9. Pločica oklopa od bakrene legure, stanje prije (lijevo) i nakon radova (desno). Dimenzije: $27 \times 17 \mathrm{~mm}$ (fototeka HRZ-a, snimio ). Škudar, 2018.)

Copper-alloy armour scale, condition before (left) and after (right) conservation. Dimensions: 27 x 17 mm (HRZ Photo Archive; ). Škudar, 2018)

restauratorskog zavoda uz financijsku potporu Ministarstva kulture Republike Hrvatske. Metalni i koštani predmeti pronađeni $u$ istraživanjima tumula 21989. godine $^{36}$ zaprimljeni su u radionicu Odjela za restauriranje arheoloških nalaza početkom 2018. godine ${ }^{37}$ i dovršeni do kraja 2019. godine. Riječ je o brojnim predmetima od željeza i bronce te malobrojnim predmetima od kosti. Najviše je dijelova koji pripadaju složenom ljuskastom oklopu od kombiniranih brončanih i željeznih pločica, povezanih zakovicama. Pločice su vjerojatno zakovicama i strunom bile pričvršćene na podlogu od kože koja je ne samo povećavala udobnost prilikom nošenja nego je i povećavala stupanj zaštite nositelju oklopa. ${ }^{38}$ Radi se o iznimno učinkovitom defenzivnom oružju koje je onome koji ga je nosio pružalo kvalitetnu i fleksibilnu zaštitu, posebno ratnicima na konjima, pa ne iznenađuje što su ga upotrebljavali Asirci, Skiti i Rimljani (lat. lorica squamata), ali i narodi kasnijega vremena. ${ }^{39}$ Najbrojnije su pločice sa zaobljenim donjim dijelom, izrađene od obiju navedenih kovina (sl. 8), pri čemu je nešto manji udio željeznih. Iako se može pretpostaviti da nisu sve pločice oklopa sačuvane, zbog rituala spaljivanja, vjerojatno je u originalu dvobojni oklop (zlatno-žute boje polirane bronce i sivo-srebrne boje željeza) bio ne samo funkcionalan nego i vizualno atraktivan. Četvrtaste pločice (sl. 9) nađene su u dvije različite dimenzije; one manje spojene su u kombinaciji sa zaobljenima i povezane zakovicom. Evidentirana su tri tipa zakovica (ovisno o obliku glave): s plitko zaobljenom glavom, s duboko zaobljenom glavom i sa šiljastom glavom. Nažalost, zbog izloženosti visokoj temperaturi vatre tijekom pogrebnog rituala, većina je pločica oštećena, deformirana ili sasvim rastopljena, tako da nije sasvim jasno pripadaju li sve oklopu pokojnika ili su neki segmenti dio opreme konja. Dio predmeta čine i ukrasne perle i privjesci od bronce, kao i dijelovi ukrasnih okova od bronce i željeza, za koje se pretpostavlja da pripadaju 


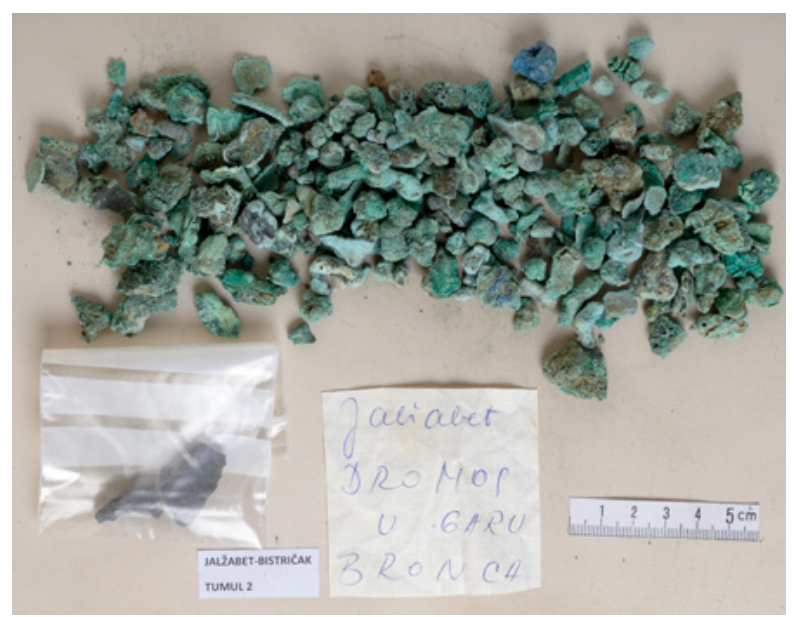

10. Ostaci rastopljene bronce i željeza iz tumula 2, stanje prije radova (fototeka HRZ-a, snimio J. Škudar, 2018.)

Remains of melted bronze and iron from tumulus 2, condition before conservation (HRZ Photo Archive; J. Škudar, 2018)

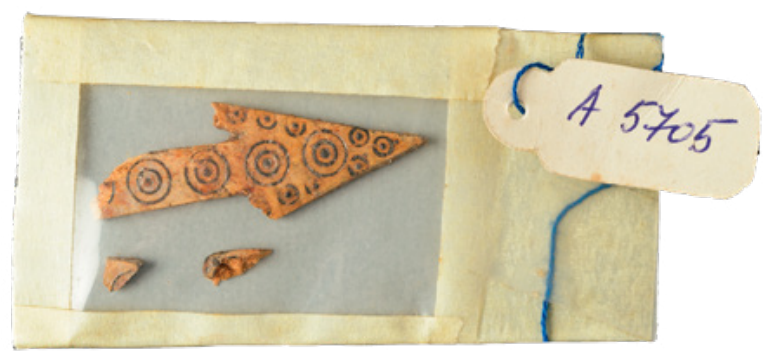

11. Improvizirano, nepravilno pakiranje oštećene koštane strelice (fototeka HRZ-a, snimio J. Škudar, 2019.)

Improvised, improper packaging of a damaged bone arrow head (HRZ Photo Archive; J. Škudar, 2019)

različitim predmetima. Osim metalnog oklopa i predmeta ukrasne namjene, obrađena su i tri vrha željeznih strelica. Opsežnost i složenost konzervatorsko-restauratorskih radova najbolje pokazuju brojevi. Zaprimljeno je 86 vrećica i kutija s ukupno 2281 predmetom, od čega su 1692 brončana i 589 željeznih. Od toga je čitavih ili bolje sačuvanih s pripadajućim inventarnim brojevima bilo 109, dok su ostali u većem ili manjem stupnju termički oštećeni - od blago deformiranih do sasvim amorfnih nakupina rastopljene bronce (sl. 10). Od koštanih predmeta zaprimljeno je devet potpuno ili djelomično sačuvanih dekorativnih strelica i četiri ulomka. Pri preliminarnom pregledu i fotografiranju postojećeg stanja zaprimljenih predmeta iz tumula 2, uočeni su problemi: neprikladno pakiranje i prethodni pokušaji restauratorskih zahvata. Pakiranje je bilo raznovrsno. Predmeti su bili upakirani u plastične kutije za sitni alat, $u$ metalne kutije od krema, papirnate vrećice i salvete, kartonske kutije i, u manjoj mjeri, $u$ polietilenske vrećice. Neki nalazi su pakirani i u kombinaciji više neadekvatnih materijala, npr. koštana strelica zamotana je u dijelove plastične folije, papira i papirnate ljepljive trake (sl. 11). Upotrijebljeni kartoni i papiri nisu bili prikladni, beskiselinski. Većina metalnih predmeta bila je stoga sasvim nezaštićena i izložena promjenama temperature i vlage, koje uzrokuju koroziju i raspadanje kovine.

Prateća dokumentacija o restauratorskim zahvatima na zaprimljenim predmetima nije postojala; određene informacije prenosile su se usmenim putem. Dio dobro očuvanih predmeta bio je označen muzejskim inventarnim brojem ispisanim na papiriću i pričvršćenim za predmet koncem. Uz preostale predmete bile su priložene, uglavnom nečitko, olovkom na komadima papira ispisane opisne signature, što je otežavalo identificiranje pojedinih cjelina s predmetima u kutijama ili vrećicama, nužno u obradi predmeta (sl. 10). Za usporedbu, predmeti pronađeni u novim istraživanjima na lokalitetu Gomila zaprimljeni su prikladno zapakirani u polietilenske patentne vrećice ili foliju, s čitkim i jasnim signaturama napisanima vodootpornim flomasterom na plastičnoj foliji i spremljeni u čvrste plastične kutije. Tako su predmeti bili zaštićeni od daljnjeg propadanja do pravovremenog dolaska $u$ restauratorsku radionicu.

Željezni su predmeti iz tumula 2 bili u lošem stanju, jer nikad nisu podvrgnuti procesu odsoljavanja, posljedica čega je više desetljeća konstantnog propadanja i korodiranja. Poznate su bile samo usmene informacije o upotrebi laka Paraloid i polivinil-acetatnog ljepila na vodenoj bazi, tvorničkog naziva Drvofix, na pojedinim predmetima. Neki predmeti od bakrene legure bili su očigledno čišćeni (najvjerojatnije pjeskarenjem), a neki premazani lakom preko korozivnog sloja. Dekorativne strelice izrađene od kosti ili roga bile su djelomično premazane, lijepljene ili rekonstruirane polivinil-acetatnim ljepilom (PVA) Drvofix, koje je nakon više od trideset godina propalo, dobrim dijelom i zbog pogrešne metode upotrebe, a možda i uvjeta skladištenja predmeta. Navedeno stanje zaprimljenih predmeta zahtijevalo je složene zahvate detektiranja i uklanjanja starih intervencija, kao i primjenu suvremenih metoda konzerviranja materijala, da bi se predmeti spasili od daljnjeg propadanja. S obzirom na kratak rok za dovršenje radova na iznimno velikom broju predmeta (i s tim povezana financijska ograničenja), nije bilo moguće provesti duge i složene laboratorijske analize, nego je postojeće stanje i utvrđivanje materijala primijenjenih $u$ prethodnim zahvatima analizirano $u$ radionici dostupnom laboratorijskom opremom i binokularnim povećalom. Restauratori su u istraživanju zatečenog stanja utvrdili vrste oštećenja i stare restauratorske zahvate te ustanovili metode koje treba primijeniti tijekom zahvata, pri čemu su se mogli osloniti na svoje bogato, višegodišnje iskustvo u radu na takvim materijalima. Osim toga, veći dio predmeta već je bio kontaminiran prethodnim zahvatima, pa bi rezultati analiza bili vrlo upitni, a analize pigmenata i materijala već su prethodno provedene prije zaprimanja materijala $u$ radionicu. 

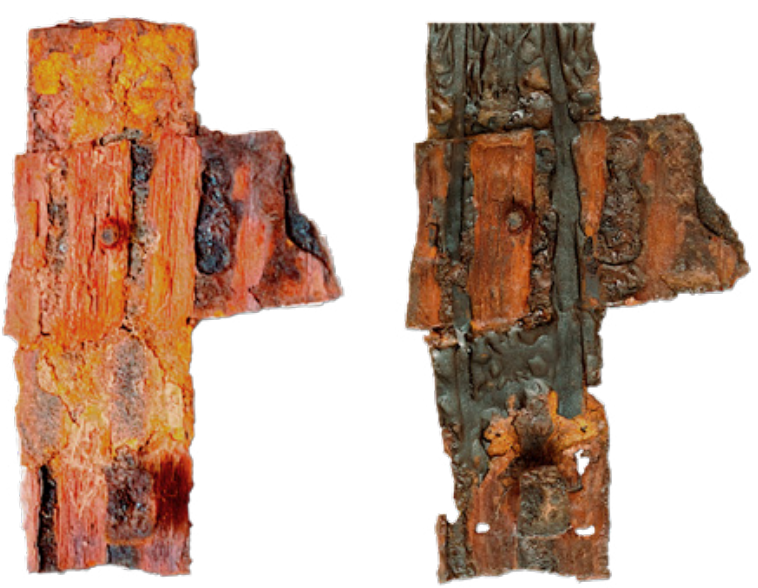

12. Detalj željeznog okova, stanje prije (lijevo) i nakon radova (desno). Dimenzije: 85 x 30 mm (fototeka HRZ-a, snimio I. Marinković, 2019.)

Detail of iron fittings, condition before (left) and after (right) conservation. Dimensions: 85 × 30 mm (HRZ Photo Archive; I. Marinković, 2019)

\section{Radovi na metalnim predmetima}

Svi su metalni predmeti tijekom pogrebnog rituala bili izloženi vatri pa se velik dio onih izrađenih od bakrene legure rastopio i pretvorio $\mathrm{u}$ amorfne grudice kovine (sl. 10); temperatura ipak nije bila dovoljno visoka za taljenje željeza. Dio predmeta, vjerojatno i zbog položaja na lomači tijekom spaljivanja, nije bio jače oštećen, a neki su bili samo djelomično deformirani termičkim djelovanjem.

Željezni predmeti iz tumula 2 bili su tako oštećeni korozijom da gotovo nije bilo sačuvane čvrste metalne jezgre. Na lomovima, pod povećanjem i tijekom sondiranja površine skalpelom, bilo je vidljivo da je izvorna površina predmeta očuvana većinom u mineraliziranom sloju čvrste korozije, dok čvrsta, željezna jezgra uglavnom nije ni postojala ili je sačuvana u manjoj mjeri. Stoga su predmeti vrlo krhke i lomljive strukture, a njihovu je izvornu površinu tijekom restauriranja trebalo pažljivo tražiti ispod površinskog sloja korozije. ${ }^{40}$ Među željeznim predmetima nalazili su se prije spomenuti dijelovi oklopa (sl. 8), tri vrha strelica i veći broj ulomaka okova drvene kutije ili namještaja (sl. 12). Na donjoj strani ulomaka tih okova, tijekom uklanjanja korozije nađeni su ostaci, vjerojatno, drvenih traka koje upućuju na to da je predmet bio ukrašen, možda nekom vrstom intarzije ili kombiniranjem dviju vrsta materijala u ponavljajućem, paralelnom slijedu. Nažalost, sačuvani su samo ostaci ostataka uskih traka, orijentiranih poprečno na plosnate šipke okova. Tragovi traka za koje se može pretpostaviti da su ostatak drvene podloge, samo su neka vrsta "slike“ u sloju korozije koji je ostatak izvorne površine, pa ih je nemoguće detaljnije analizirati. Možda su predmeti s kojih potječu željezni okovi bili ukrašeni različitim vrstama drva raznih nijansi te intarzijama od urezanih i slikanih kostiju, što ne bi bio prvi takav slučaj na nalazima iz halštatskog razdoblja. ${ }^{41}$ Ulomci okova iz tumula $2 \mathrm{u}$ Jalžabetu zastupljeni su primjercima različitih širina i dužina, a neki su međusobno spojeni zakovicama (sl. 12). Debljina šipki okova iznosi oko 1-2 mm, a širina 3-5 cm. Neke imaju glatke, a neke lagano nazubljene rubove kao vrstu ukrasa. Samo je neke ulomke bilo moguće spojiti u cjeline, stoga nije bilo moguće rekonstruirati potpuni izgled okova niti odrediti pripadaju li samo jednom predmetu ili više njih. Može se pretpostaviti da su bar neke trake okova bile zakovicama povezane $u$ vrstu široke mreže s presavijenim trokutasto povezanim krajevima i tako obuhvaćale vanjsku površinu predmeta s više strana. O funkciji i izgledu izvornog predmeta teško je nagađati. Moglo se raditi o komadu namještaja, štitu ili čak kolima, čiji nam ostali dijelovi nedostaju među pronađenim i restauriranim predmetima iz tumula 2.

Oklop od željeznih i brončanih pločica bio je vrlo složene kombinirane konstrukcije koju je činilo više vrsta pločica, tri vrste zakovica i dvije vrste kovine. Zbog izloženosti visokoj temperaturi, neke pločice i zakovice ostale su međusobno djelomično staljene, i to one od željeza i one od bronce zajedno, tako da se sa sigurnošću može reći da je oklop bio kombiniran od dvaju metala složenih prema modelu ljuski. Ostaci metalnih oksida na rupama u pločicama (koje variraju po broju i promjeru) i nekoliko sačuvanih kombinacija pločica i zakovica, pokazuju vrhunski zanatski rad, koji je u svojem punom sjaju, na ratniku iz željeznog doba, morao biti zaista impresivan. Premda su restauratori tijekom radova uspjeli spojiti nekoliko ulomaka pločica u cjelinu, stupanj oštećenja ne dopušta čak ni djelomičnu rekonstrukciju izgleda. Jedino preostaje mogućnost idejnih rekonstrukcija u crtežu. Može se pretpostaviti da su se pločice manjih dimenzija, kao i čvršće željezne pločice, nalazile bliže zglobovima i pomičnim dijelovima tijela i tako omogućavale bolju pokretljivost, ali i kvalitetniju zaštitu ratniku koji je oklop nosio. Slično su zaključili istraživači koji su analizirali druge oklope, primjerice na (Jalžabetu kulturno i kronološki bliskom) lokalitetu Regöly, u okrugu Tolna u Mađarskoj, gdje je pronađena najveća količina pločica ljuskastog oklopa na jednom mjestu u Karpatskoj kotlini. ${ }^{42}$

Svi željezni predmeti iz Jalžabeta prije svega su trebali proći proces odsoljavanja u sulfitnoj kupki ${ }^{43}$ (šest mjeseci). Trajanje procesa određeno je empirijski prema prethodnom višegodišnjem iskustvu. ${ }^{44}$ Korozivne naslage uklonjene su mikrobrusevima i pjeskarenjem s pomoću agregata korunda (100 mikrona) pod tlakom od dva do pet bara. Dio predmeta površinski je tretiran taninom otopljenim u etanolu koji pomaže u zaštiti od daljnjeg korodiranja i ujednačava boju površine. ${ }^{45}$ Šipke okova konsolidirane su natapanjem u Paraloidu B72 (5\%), a pukotine popunjavane epoksidom Araldite 2020. No spojevi su i dalje bili krhki i lomljivi pa su s donje strane 

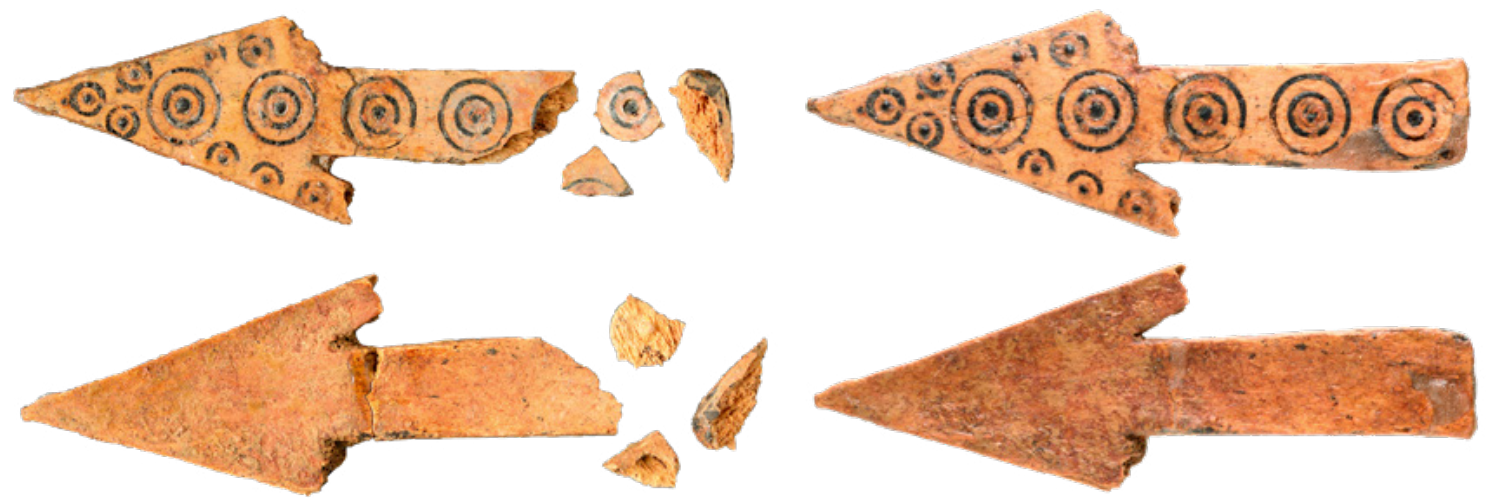

13. Fragmentirana koštana strelica s prednje i stražnje strane, stanje prije (lijevo) i nakon radova (desno). Dimenzije: 50 x $17 \mathrm{~mm}$ (fototeka HRZ-a, snimio J. Škudar, 2019.)

Fragmented bone arrow head from front and back, condition before (left) and after (right) conservation. Dimensions: 50 x $17 \mathrm{~mm}$ (HRZ Photo Archive; J. Škudar, 2019)
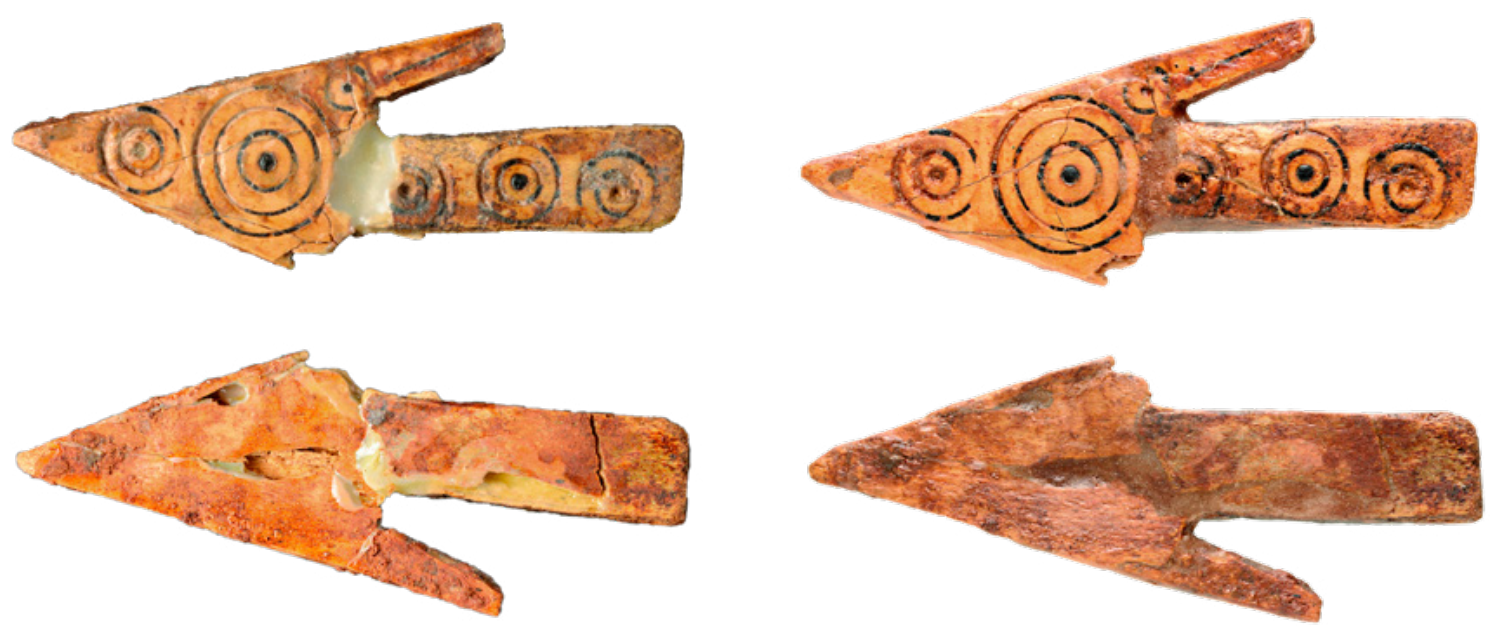

14. Koštana strelica na kojoj su uklonjeni stari restauratorski zahvati s prednje i stražnje strane, stanje prije (lijevo) i nakon radova (desno). Dimenzije: 48 × 20 mm (fototeka HRZ-a, snimio J. Škudar, 2019.)

Bone arrow head on which the removal of old restoration interventions from the front and back was performed, condition before (left) and after (right) conservation. Dimensions: 48 × 20 mm (HRZ Photo Archive; J. Škudar, 2019)
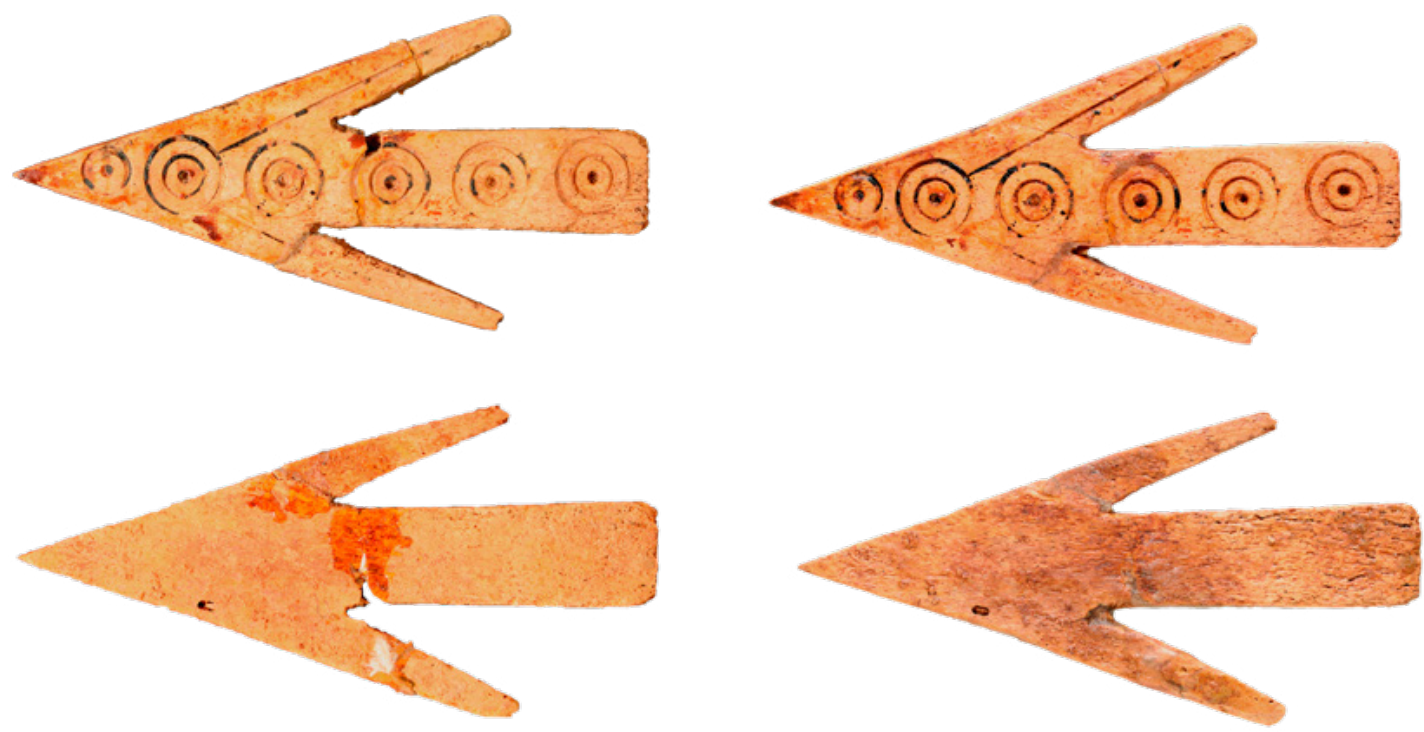

15. Cjelovita koštana strelica s prednje i stražnje strane, stanje prije (lijevo) i nakon radova (desno). Dimenzije: 50 × $25 \mathrm{~mm}$ (fototeka HRZ-a, snimio J. Škudar, 2019.)

Complete bone arrow from front and back, condition before (left) and after (right) conservation. Dimensions: $50 \times 25 \mathrm{~mm}$ (HRZ Photo Archive; J. Škudar, 2019) 
epoksidom i nitima od fiberglasa postavljena ojačanja. Epoksid je toniran smeđim i grafitnim pigmentom $u$ prahu da bi se ujednačio s bojom željeza. Površina predmeta zaštićena je lakom Paraloid B72 i potom mikrokristalinskim voskom Cosmoloid H80. Premda se $u$ restauratorskoj praksi često upotrebljava njihova mješavina Parawax, koja se nanosi odjednom, odvojeno nanošenje najprije Paraloida B72, a potom Cosmoloida H80 ipak se pokazalo boljim, jer je lakše kontrolirati završni izgled.

Predmeti od bakrene legure, kao što su pločice oklopa (sl. 9), privjesci, perle i ukrasni okovi, većinom nisu bili strukturalno čvrsti te su pokazivali znakove aktivne korozije. Zbog toga su, nakon čišćenja, tretirani umakanjem $\mathrm{u}$ otopinu BTA. ${ }^{46}$ Dio predmeta iz tumula 2 koji je zaprimljen s premazom laka Paraloid B72 ispran je umakanjem $\mathrm{u}$ acetonu kako bi se moglo provesti uklanjanje korozivnih naslaga i tretman otopinom BTA. Korozivni sloj uklonjen je do izvorne površine raznim laboratorijskim priborom (poput skalpela s različitim nastavcima i mekane četkice za mikromotor). ${ }^{47} \mathrm{Na}$ dijelu amorfnih, rastopljenih predmeta primijenjen je mikropjeskarnik s agregatom staklenih kuglica od 40 mikrona na tlaku do jednog bara. Ultrazvučni alati nisu korišteni zbog lošeg stanja metala, jer bi mogli izazvati raspadanje predmeta. Radovi su obavljani pod binokularnim povećalom s povećanjem pet do deset puta ili vizir-naočalama s povećanjem do pet puta. Površina je, nakon čišćenja i tretmana BTA-om, premazana ili impregnirana umakanjem u 2-5\%-tnoj otopini laka Paraloid $B 72 \mathrm{u}$ acetonu. Time su predmeti konsolidirani, ali i sigurni za daljnje rukovanje zbog kancerogenosti BTA. Za lijepljenje fragmenata ili konsolidaciju spojeva i popunjavanje rupa i pukotina upotrijebljen je epoksid Araldite $2020 \mathrm{~s}$ punilom zelenog ili smeđeg pigmenta $\mathrm{u}$ prahu. Na kraju je površina premazana mikrokristalinskim voskom Cosmoloid H80 otopljenim u toluenu, koji štiti od utjecaja vlage i u daljnjem rukovanju, a nakon laganog poliranja mekom četkicom ili kistom daje estetski prihvatljivu polusjajnu površinu.

\section{Radovi na strelicama od roga ili kosti}

Dekorativne strelice od roga ili kosti nisu bile oštećene vatrom. Na njima nisu uočeni tragovi koji bi upućivali na to da su bile pričvršćene na neki veći predmet. Naime, vizualno nisu primijećeni tragovi lijepljenja, ni urezi ili rupice koji bi navodili na moguće zakivanje ili prišivanje. Na naličju strelica također izostaju tragovi kontaminacije površine mineralima izazvani kontaktom s oksidiranom površinom kovine, koji u slučaju bronce obično boje kost zeleno (mineral malahit), ${ }^{48}$ a željezo crvenkasto-smeđe (minerali hematit ${ }^{49} \mathrm{i}$ hidrohematit ${ }^{50}$ kao dva primjera mogućih željeznih oksida). Samo je jedan manji ulomak strelice kontaminiran tamnim površinskim nečistoćama koje vjerojatno potječu od pepela u zemlji. Strelice su

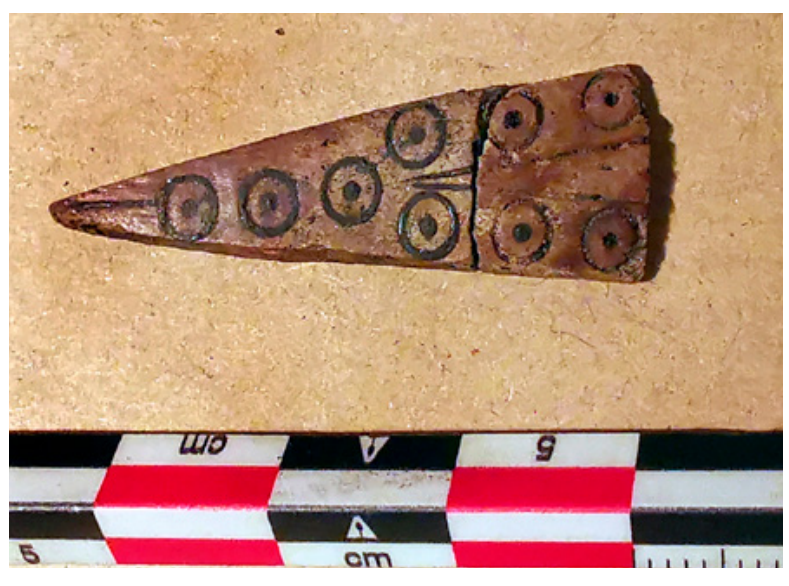

16. Koštani trokut s lokaliteta Gomila, stanje prije radova (IA, snimio S. Kovačević, 2019.)

Bone triangle from Gomila, condition before conservation (IA; S. Kovačević, 2019)

tijekom tisućljeća bile izložene djelovanju vlage i štetnih soli iz zemlje. Zbog toga su bile vrlo krhke, a neke su pronađene u dijelovima (sl. 13 i 14). Samo su dvije strelice cjelovite, sedam ih je djelomično sačuvanih, a zaprimljena su i četiri ulomka (sl. 15). Strelice su ukrašene različitim kombinacijama motiva (najmanje četiri kombinacije) koncentričnih kružnica različite veličine i položaja. Unutrašnjost ureza kružnica bila je zapunjena crnom bojom, a na gornjoj, ukrašenoj površini postoje i manji tragovi crveno-smeđe boje. Vrijedi spomenuti da su u radionice HRZ-a zaprimljeni i predmeti od kosti ili roga sa sličnim dekorativnim konceptom u obliku izduženih trokuta, pronađeni tijekom zaštitnih istraživanja Gomile $u$ Jalžabetu $u$ protekle tri godine. Kao i nalazi iz tumula 2, ni ti primjerci nisu gorjeli. Ukrašeni su kombinacijom urezivanja te crnim i crvenim pigmentom (sl. 16). Nekadašnji zahvati na strelicama iz tumula $2 u$ Jalžabetu uključivali su najvjerojatnije inicijalno pranje površine vodom i nekom vrstom četkice ili spužve, čime je uklonjena zemlja, koje je ipak ponegdje ostalo $u$ tragovima na površini (posebno s donje strane koja nije glatka). Nakon toga su fragmenti spajani PVA ljepilom, a dio strelica je njime i površinski premazivan. Gusti PVA nalijevan je $u$ pukotine i na slabe spojeve, u pokušaju konsolidacije i rekonstrukcije predmeta. Inicijalno lagano prozirne bijele boje i elastičan, PVA je starenjem požutio i postao krt, dok je struktura kosti ostala krta i lomljiva. Na mjestima na kojima ljepilo nije ušlo dublje u poroznu strukturu, spojevi su se počeli odvajati, odnosno do odvajanja je došlo odmah iza granice prodora ljepila. Da bi se PVA ljepilom na vodenoj bazi ulomci dobro spojili, potrebno je spoj najprije tretirati vodom, a zatim i 2-5\%-tnom otopinom ljepila u vodi koja služi i kao konsolidant. U ovom slučaju je zasigurno PVA nanošen na suhu podlogu i s vremenom je sasvim izgubio ljepljiva svojstva (sl. 15). Staro je ljepilo tijekom preliminarnih istraživanja dobro reagiralo na 95 
\%-tni etilni alkohol, što i jest karakteristika PVA, koji se na taj način može otapati i uklanjati s površine. Stoga je stari PVA pažljivo uklonjen etanolom, kistom, vatenim štapićima, pincetom i skalpelom pod povećanjem od pet do deset puta. Na pojedinim manjim površinama PVA je ostavljen, kako njegovo potpuno uklanjanje iz porozne površine presjeka kosti ne bi uzrokovalo daljnje oštećenje. Ukrašene strelice zatim su premazane kistom ili natopljene umakanjem 5 \%-tnom otopinom laka Paraloid B72 $\mathrm{u}$ acetonu te tako konsolidirane. Ulomci su međusobno zalijepljeni 50 \%-tnim Paraloidom B72. Rupe i pukotine koje su ugrožavale čvrstoću spojeva ulomaka zapunjene su epoksidnim dvokomponentnim ljepilom UHU epoxy+ uz dodatak talka i male količine smeđeg pigmenta $u$ prahu, kako bi rekonstruirana površina sličila boji kosti. Epoksid je oprezno brušen i oblikovan mikromotorom, a površina zaštićena Paraloidom B72 (2 \%-tnim). Time su strelice postale dovoljno čvrste za rukovanje i sačuvane od daljnjeg propadanja (sl. 14). Paraloid B72 i epoksid su reverzibilni i mogu se u slučaju potrebe s površine ukloniti acetonom. Koautor svoje zahvate i metodologiju temelji na osobom iskustvu u radu s raznim PVA proizvodima, koji su se prije trideset ili više godina uobičajeno primjenjivali u restauratorskoj praksi, posebno pri restauriranju keramičkih, ali i koštanih predmeta. ${ }^{51} \mathrm{U}$ međuvremenu je višegodišnje praćenje stanja predmeta tretiranih PVA-om dovelo do saznanja o prednostima i manama, a posljedično tome i promjena $u$ primjeni, kao i do postupne zamjene prikladnijim, novim materijalima. ${ }^{52}$

\section{Zaključak}

Kao što je uvijek bilo generacijama prije nas, a bit će $\mathrm{i}$ poslije nas, arheolozi su se trudili što je moguće bolje istražiti, dokumentirati, a potom i restaurirati arheološke nalaze. Pri kompleksnim arheološkim istraživanjima (a upravo je takvo istraživanje tumula starijega željeznog doba) veliki su problemi vrijeme i nedostatak financijskih sredstava. Tako je bilo u slučaju Martijanca, a poslije i

\section{Bilješke}

1. MARINA ŠIMEK, SAŠA KOVAČEVIĆ, 2014. Zahvaljujemo muzejskoj savjetnici u miru Marini Šimek, dugogodišnjoj kustosici Gradskog muzeja Varaždin, koja nam je od početka pružala snažnu podršku i mnogo pomogla u organizaciji i provedbi arheoloških istraživanja u Jalžabetu, ali i u konzerviranju arheoloških nalaza iz tumula 2 u jalžabetu. Također zahvaljujemo i recenzentima koji su konstruktivnim prijedlozima uvelike utjecali na konačnu kvalitetu ovoga rada.

2. S. Kovačević, kao član zbelavske ekipe, 1997. godine prvi je put posjetio Gomilu u Jalžabetu. Zaštitna arheološka istraživanja na trasi autoceste Goričan - Zagreb u Zbelavi na položaju Pod lipom, oko pet kilometara zračne linije sjeverozapadno od Gomile
Jalžabeta. Nažalost, i arheološka istraživanja u Martijancu, kao i istraživanja obaju tumula u Jalžabetu, dogodila su se nakon što su na spomenicima nastala ozbiljna oštećenja i zapravo su imala karakter zaštitnih istraživanja, čime se ponovo upozorava na potrebu promišljenije zaštite vrlo osjetljivih prapovijesnih nalaza, lokaliteta i krajolika u Republici Hrvatskoj i Europi. Danas moderna i prema našem sudu kvalitetna arheološka istraživanja Gomile u Jalžabetu zasigurno će se u nekoliko desetljeća činiti anakrona i u mnogočemu nedostatna. Metodologija arheoloških istraživanja, kao i restauriranja arheoloških nalaza, uvelike je napredovala od vremena iskopavanja tumula 2. Problem revizije nekadašnjih restauratorskih zahvata postavlja velik izazov pred današnje restauratore, pri čemu je posebno problematičan nedostatak prateće restauratorske dokumentacije. No prilikom revizije stječu se i važne spoznaje o tome kako se pojedini materijali upotrijebljeni $u$ restauriranju ponašaju $u$ testu vremena. Zbog specifičnih okolnosti pogrebnog rituala i različitih prirodnih i antropogenih utjecaja na nalaze proteklih tisućljeća, pa sve do danas, interpretacija nalaza iz tumula u Jalžabetu vrlo je kompleksna. Upravo restauriranje nalaza, detaljne analize konteksta, arheoloških slojeva i struktura, a potom i najsitnijih nalaza pronađenih flotacijom, pomoći će nam $u$ razumijevanju onoga što se $u$ Jalžabetu događalo prije više od 2500 godina. Pri tome će ključnu ulogu imati stručnjaci raznih profila koji su već uključeni u analizu uzoraka i drugih arheoloških nalaza. Na grobnom humku Gomila nastavljaju se arheološka iskopavanja koja prate konzervatorsko-restauratorski radovi na pronađenim predmetima. Timski rad arheologa, restauratora i ostalih uključenih znanstvenika sve više sliči kompleksnoj forenzičkoj istrazi. No dok je restauratorski posao na nalazima iz tumula 2 dovršen, radove na nalazima iz Gomile čeka višegodišnja obrada, da bi bili sačuvani za buduće naraštaje i da bi upotpunili znanstvene spoznaje o halštatskom razdoblju željeznoga doba na lokalitetu Jalžabet.

u Jalžabetu, 1997. godine vodio je Amelio Vekić iz Konzervatorskog odjela u Zagrebu. Uz velikodušnu pomoć A. Vekića, gotovo desetljeće poslije arheološki nalazi iz iznimno važnog kasnohalštatskog naselja u Zbelavi poslužit će kao osnova analizama u magistarskom, a potom i doktorskom radu S. Kovačevića (SAŠA KOVAČEVIĆ, 2005., 2007., 2008.).

3. Zahvaljujem svim kolegama iz navedenih ustanova na trudu i dosadašnjim, preliminarnim rezultatima analiza.

4. Napominjemo da dug proces flotacije svih arheoloških slojeva iz Gomile traje usporedno s arheološkim istraživanjima u Jalžabetu; dok se pisao ovaj rad, taj posao još nije priveden kraju. 
5. Za više informacija o genezi i analizi zlata u Dravi i Muri vidjeti u: VLADIMIR BERMANEC et al., 2014.

6. SAŠA KOVAČEVIĆ, 2016., 2018., 2020.b (u tisku)

7. Za preliminarne analize o porijeklu oblutaka iz Gomile i tumula 2 zahvaljujem geologu Dubravku Šinceku i Marini Šimek. 8. Za više informacija o porijeklu i petrografsko-mineraloškom sastavu Podravine vidjeti u: DRAGUTIN FELETAR, 2016.

9. Zahvaljujem na pomoći pri očitanju snimke LiDAR-om prof. dr. M. Doneusu i M. Feri sa Sveučilišta u Beču (Institut für Urgeschichte und Historische Archäologie, Historisch- Kulturwissenschaftliche Fakultät, Universität Wien). Rezultate analize te snimke Institut za arheologiju planira provjeriti nizom ciljanih arheološih rekognosciranja.

10. MIROSLAV FULIR, 1961. Prema najčešćoj inačici lokalne legende, Gomila je nastala tako što su Turci donosili u turbanima zemlju na grob svojega palog vojskovođe, kako bi mu na taj način iskazali počast i obilježili mu grob. (MARINA ŠIMEK, 1995., 10; MARINA ŠIMEK, SAŠA KOVAČEVIĆ, 2014., 232).

11. MARINA ŠIMEK, 1980.

12. KSENIJA VINSKI-GASPARINI, 1961.

13. KSENIJA VINSKI-GASPARINI, 1978., bilj. 49a. Zahvaljujem kolegici Jacqueline Balen i Arheološkom muzeju u Zagrebu što su mi ljubazno dopustili kopiranje i uporabu dijela terenske dokumentacije Ksenije Vinski-Gasparini iz Jalžabeta.

14. Ksenija Vinski-Gasparini 1978. godine navodi da je sondirana sjeverna i južna padina velikoga tumula u Jalžabetu i da je u sjevernoj sondi, oko četiri metra ispod razine platoa, na vrhu tumula pronađena konstrukcija od oblutaka (KSENIJA VINSKI-GASPARINI, 1978., bilj. 49a). Da je sondirana sjeverna i južna padina, spominje i Dubravka Balen-Letunić (DUBRAVKA BALEN-LETUNIĆ, 1986., 91). K. Vinski-Gasparini poslije piše da je tumul sondiran na zapadnoj i istočnoj padini te da je na dnu istočne nađena navedena konstrukcija (KSENIJA VINSKI-GASPARINI, 1984., 41). Zahvaljujući uvidu u terensku dokumentaciju iz 1960-ih, te prema arheološkim istraživanjima 2019. godine, možemo potvrditi da je struktura od oblutaka pronađena u sondi na istočnoj padini Gomile te da je druga sonda otvorena na razini okolnog tla, na zapadnoj strani tumula (SAŠA KOVAČEVIĆ, 2020. u tisku).

15. KSENIJA VINSKI-GASPARINI, 1984., 41.

16. Registar 1997., 37-38.

17. BRANKA VIKIĆ-BELANČIĆ, 1968.

18. MARINA ŠIMEK, 1998., 2001., 2003., 2004.

19. Slična situacija poznata je u Stretwegu, gdje je tek više kampanja intenzivnih geofizičih istraživanja u kombinaciji s arheološkim istraživanjima iznijelo na svjetlo dana skriveni arheološki krajolik, uključujući i zamršenu mrežu preklapajućih sniženih tumula starijega željeznog doba (SUSANNE TIEFENGRABER, GEORG TIEFENGRABER, 2019., 87).

20. MARINA ŠIMEK, 1998., 502.

21. MARINA ŠIMEK, 2001.

22. Projekt je sufinancirala Europska unija s oko 2.169 .200 eura iz ERDF-a. ERDF sredstva čine $85 \%$ financijskih sredstava projekta, dok je ukupna vrijednost projekta bila oko 2.552 .000 eura (https:// www.iron-age-danube.eu/,http://www.interreg-danube.eu/approved-projects/iron-age-danube, https://en.wikipedia.org/wiki/IronAge-Danube_project) (15. 03. 2020.).

23. KSENIJA VINSKI-GASPARINI, 1987.; MARINA ŠIMEK, 1998., 2001; SAŠA KOVAČEVIĆ, 2019.

24. SAŠA KOVAČEVIĆ, 2020.b (u tisku).

25. SAŠA KOVAČEVIĆ, 2018.b, 2020.b (u tisku).

26. SAŠA KOVAČEVIĆ, 2020.b (u tisku).

27. SAŠA KOVAČEVIĆ, 2018.b, 2019.

28. Zidovi komore tumula 1 u Jalžabetu višedijelni su i sastavljeni od različitih materijala; drvo, kamen, ugljen, oblutci i glina korišteni su u gradnji više segmenata vrlo debelih zidova komore, pa oni tlocrtno izgledaju kompozitno, kao da se radi o više "komora u komori".

29. SAŠA KOVAČEVIĆ, 2019., 121.

30. MARINA ŠIMEK, 1998., 2001.; MARINA ŠIMEK, SAŠA KOVAČEVIĆ, 2014.

31. KSENIJA VINSKI-GASPARINI, 1987., 206; BIBA TERŽAN, 1990., 205; MARCUS EGG, 2019., fig. 9.

32. VINSKI-GASPARINI, 1987.; BIBA TERŽAN, 1990.; MARCUS EGG, 1996.; MARCUS EGG, DIETER KRAMER, 2005., 2016.

33. Zahvaljujem Marku Kralju, ravnatelju Instituta za fiziku, te Marinu Petroviću s Instituta za fiziku, na SEM/EDS analizama. Pročelniku Katedre za biofiziku Medicinskog fakulteta Sveučilišta u Zagrebu Ozrenu Gamulinu te Marku Škrabiću s Katedre za biofiziku zahvaljujem na velikom trudu u analizama ukrašenih koštanih predmeta iz Jalžabeta uz pomoć FTIR i Ramanove spektroskopije. Napominjem, rezultati tih istraživanja u pripremi su za objavu u drugoj publikaciji.

34. Izdvajamo ovdje samo poznati nalaz brončane ploče ukrašene iskucavanjem iz tumula IV na Čemernici (HRVOJE POTREBICA, MARTA RAKVIM, 2019. T. 3.).

35. NEMANJA MARKOVIĆ, SONJA STAMENKOVIĆ, 2016., 223.

36. MARINA ŠIMEK, 1998., 2001., 2003., 2004.

37. Radove provedene 2018. i 2019. godine vodio je Mihael Golubić, a u restauratorskom su timu sudjelovali Ivan Gagro, Franjo Bračun i Elena Perković Gjurašin.

38. Kako je mogao biti način pričvršćenja ljuskica oklopa na podlogu, vidi ilustraciju eksperimenta u: MARINA ŠIMEK, 2004., 122.

39. Reallexikon 27, 375-385.

40. DAVID A. SCOTT, JERRY PODANY, BRIAN B. CONSIDINE, 2007.

41. MILOSLAV CHYTRÁČEK et al., 2018., Abb. 16.

42. VERONIKA HORVATH, GÉZA SZABÓ, 2015., 101.

43. Željezo je podvrgnuto aktivnoj stabilizaciji postupkom uklanjanja soli (primarno klorida) u sulfiitnoj kupki ( $\mathrm{Na} 2 \mathrm{SO} 3+\mathrm{NaOH}+\mathrm{H} 2 \mathrm{O}$ ). Postupak: željezni predmeti, nakon površinskog mehaničkog čišćenja ostataka zemlje, pakiraju se u polipropilensku mrežicu s pripadajućom signaturom i potapaju u kadu za desalinizaciju. Kada se potom puni otopinom natrijeva sulfita $(6,3 \%)$ i natrijeve lužine u destiliranoj vodi. Uvjeti su anaerobni; kada je hermetički zatvorena da ne bi došlo do oksidacije sulfita u sulfat koji bi razorio materijal. Otopina u kadi za sulfitni postupak cirkulira na 
temperaturi od $50^{\circ} \mathrm{C}$ te se mijenja jedanput mjesečno (ANTONIJA MALETIĆ, 2010., 272).

44. MIHAEL GOLUBIĆ, 2013., 202.

45. MIHAEL GOLUBIĆ, 2013., 202.

46. Benzotriazol (C6H5N3 $5 \%$ u etanolu), parnofazni inhibitor korozije; vežući se za kuprit, blokira nastanak nantokita, bazičnog bakrenog klorida, a time i daljnju cikličku korozijsku reakciju (JANEY M. CRONYN, 2005., 228-229; ANTONIJA MALETIĆ, 2010., 272).
47. MAŠA VUKOVIĆ BIRUŠ, MIHAEL GOLUBIĆ, 2014., 105-109.

48. $\mathrm{Cu} 2 \mathrm{CO} 3(\mathrm{OH}) 2$

49. $\mathrm{Fe} 2 \mathrm{O} 3$

50. $\mathrm{Fe} 2 \mathrm{O} 3 \times \mathrm{H} 2 \mathrm{O}$

51. HERMANN KÜHN, 1987.

52. SUSAN BUYS, VICTORIA OAKLEY, 2007.

\section{Literatura}

DUBRAVKA BALEN-LETUNIĆ, Miholjanec - tumul "Gomilica“, Đurđevac, u: 40 godina arheoloških istraživanja u sjeverozapadnoj Hrvatskoj, katalog izložbe, Bjelovar - Koprivnica, 1986., 102. VLADIMIR BERMANEC, LADISLAV PALINKAŠ, MARIN ŠOUFEK, VLADIMIR ZEBEC, Zlato u Dravi i Muri - geološka geneza i mineraloška analiza, Podravina, vol. 13, broj 25 (2014.), 7-18.

SUSAN BUYS, VICTORIA OAKLEY, Conservation and Restoration of Ceramics, Oxford, 2007.

MILOSLAV CHYTRÁČEK, ONDŘEJ CHVOJKA, MARKUS EGG, JAN JOHN, RENÉ KISELÝ, JAN MICHÁLEK, PETRA STRÁNSKÁ, Späthallstattzeitliches Fürstengrab von Rovná in Südböhmen. Symbolische Kunstform der Elite 6./5. Jahr. v. Chr., ihre Inspiration und Funktion, Inspirationen und Funktionder ur- und frühgeschichtlichen Kunst, Biskupiner Archäologische Arbeiten, 13, Arbeiten der Archäologischen Kommission, 22, (ur.) Boguslaw Gedigi, Anny Grossman, Wojciech Piotrowskie, Biskupin - Wrocław, 2018., 283-319.

JANEY M. CRONYN, The Elements of Archaeological Conservation, Routledge, London and New York, 1990.

MARCUS EGG, Princely graves from Kleinklein in Styria, Austria, Arheološki vestnik, 70 (2019.), 335-352.

MARCUS EGG, Das hallstattzeitliche Fürstengrab von Strettweg bei Judenburg in der Obersteiermark, Monographien des RömischGermanischen Zentralmusuem, 37, 1996.

MARCUS EGG, DIETER KRAMER, Krieger-Feste-Totenopfer. Der letzte Hallstattfürst von Kleinklein in der Steiermark, Mosaiksteine Forschung des Römisch-Germanisches Zentralmuseum, 1, 2005. MARCUS EGG, DIETER KRAMER, Die hallstattzeitlichen Fürstengräber von Kleinklein in der Steiermark: Die beiden Hartnermichelkogel und der Pommerkogel, Monographien des Römisch-Germanischen Zentralmusuem, 125, 2016.

DRAGUTIN FELETAR, Geneza i eksploatacija šljunka i pijeska na području Šoderice, Podravina, vol. 15, broj 29 (2016.), 24-35. MIROSLAV FULIR, Mogile u okolici Varaždina, Varaždinske vijesti, 8. i 15. 6. 1961., 1961.

MIHAEL GOLUBIĆ, Restauriranje avarskih metalnih nalaza s lokaliteta Nuštar, dvorac Khuen-Belassy, Portal, 4 (2013.), 201-206. VELSON HORIE, Materials for Conservation, Routledge, New York, 2010.

VERONIKA HORVATH, GÉZA SZABÓ, Scythian Age Scale Armour from the Tumulus at Regöly, Proceedings of International scientific and practical conference «VII Orazbayev readings» «Kazakh
Archaeology and Ethnology: Past, Present and Future», dedicated to the 550th anniversary of the Kazakh Khanate, the 20th anniversary of the Assembly of People of Kazakhstan 28-29 April, Almaata, 2015., 100-105.

SAŠA KOVAČEVIĆ, Naseljenost sjeverozapadne Hrvatske u starijem željeznom dobu, neobjavljeni magistarski rad, Filozofski fakultet Sveučilišta u Zagrebu, Zagreb, 2005.

SAŠA KOVAČEVIĆ, Karakteristični nalazi kasnohalštatskog naselja u Zbelavi kod Varaždina i fibula tipa Velem, Prilozi Instituta za arheologiju u Zagrebu, 24 (2007.), 89-112.

SAŠA KOVAČEVIĆ, Osvrt na strukturu i keramičku produkciju kasnohalštatskog naselja u Zbelavi kod Varaždina, Prilozi Instituta za arheologiju u Zagrebu, 25 (2008.), 47-80.

SAŠA KOVAČEVIĆ, Jalžabet - Bistričak 2016., Hrvatski arheološki godišnjak, 13 (2016.), (u tisku).

SAŠA KOVAČEVIĆ, Arheološka istraživanja prapovijesnog lokaliteta Jalžabet - Carev jarek, sezona 2017., Annales Instituti Archaeologici, vol. XIV, br. 1 (2018.), 76-79.

SAŠA KOVAČEVIĆ, Arheološko istraživanje prapovijesnog lokaliteta Jalžabet - Bistričak u 2017. godini i Kamp Hrvatska projekta "Iron-Age-Danube“ INTERREG DTP, Annales Instituti Archaeologici, vol. XIV, br. 1 (2018.b), 72-75.

SAŠA KOVAČEVIĆ, Architecture of power or demise: gigantic burial mounds of Podravina as parts of the Eraly Iron Age landscape The Iron-Age-Danube project in the Plitvica-Bednja rivers basin (NW Croatia), Early Iron Age Landscapes of the Danube Region, (ur.) Marko Mele i Matija Črešnar, Budapest - Graz, 2019., 109-141. SAŠA KOVAČEVIĆ, Gomila u Jalžabetu - hitna zaštitna istraživanja tijekom 2017. i 2018. u okviru podteme A4: Ritual unutar „Strategije znanstvene djelatnosti Instituta za arheologiju 2014. - 2019.", Annales Instituti Archaeologici, XV(1) (2019.b), 137-143. SAŠA KOVAČEVIĆ, Nekoliko detalja o gradnji Gomile u Jalžabetu, Zbornik u prigodi 65. rođendana prof. dr. sc. Mirjane Sanader 2020., (u tisku).

SAŠA KOVAČEVIĆ, Zaštitna arheološka istraživanja tumula 1 Gomile u Jalžabetu u 2019. Annales Instituti Archaeologici XXVI (2020.b), (u tisku).

HERMANN KÜHN, The Conservation and restoration of Works of Art and Antiquities: Volume 1, Oxford, 1987.

ANTONIJA MALETIĆ, Konzervatorsko-restauratorski zahvati na fibuli od bakrene slitine i željeznom nožu s lokaliteta Jokine i Duševića Glavice u Krnezi, Portal, 1 (2010.), 269-274. 
NEMANJA MARKOVIĆ, SONJA STAMENKOVIĆ, Antler workshop in Caričin Grad (Justiniana Prima): reconstruction of the technological process, Close to the bone: current studies in bone technologies, (ur.) Selena Vitezović, Beograd, 2016., 218-226.

HRVOJE POTREBICA, MARTA RAKVIN, Tumul IV na groblju Kaptol - Čemernica - revizijsko istraživanje, Vjesnik Arheološkog muzeja u Zagrebu, vol. 52, br. 1 (2019.), 31-81.

Reallexikon, Reallexikon der Germanischen Altertumskunde, Band 27, Berlin - New York, 2004.

Registar, Registar arheoloških nalaza i nalazišta sjeverozapadne Hrvatske, Varaždin, 1990.

DAVID A. SCOTT, JERRY PODANY, BRIAN B. CONSIDINE, Ancient Q Historic metals, Los Angeles, 2007.

MARINA ŠIMEK, Arheologija varaždinskog kraja. Bibliografija, Muzejski vjesnik, Glasilo muzeja sjeverozapadne Hrvatske, 3 (1980.), 16-17.

MARINA ŠIMEK, Najstariji spomenici Jalžabeta i okolice, Općina Jalžabet, Zagreb, 1995., 10-14.

MARINA ŠIMEK, Ein Grabhügel mit Pferdebestattung bei Jalžabet, Kroatien, Das Karpatenbecken und die osteuropäische Steppe, (ur.) Bernard Hänsel i Jan Machnik, Südosteuropa-Schriften, 20, Prähistorische Archäologie in Südosteuropa, 12, München, 1998., 493-510

MARINA ŠIMEK, Weitere Aspekte von Grabhügel II in Jalžabet bei Varaždin, Die Drau, Mur-, und Raab-Region im 1. vorchristlichen Jahrtausend, (ur.) Andreas Lippert, Akten des internationalen interdisziplinären Symposiums von 26. bis 29. April 2000. in Bad Radkersburg, Universitätsforschungen zur Prähistorische Archäologie, 78, Bonn, 2001., 311-318.

MARINA ŠIMEK, Grobni humak s ukopom konja kod Jalžabeta, Izdanja Hrvatskog arheološkog društva, 21 (2003.), 57-78.

MARINA ŠIMEK, Grupa Martijanec - Kaptol, Ratnici na razmeđu istoka i zapada, Starije željezno doba u kontinentalnoj Hrvatskoj, (ur.) Dubravka Balen Letunić, Zagreb, 2004., 79-130.

MARINA ŠIMEK, SAŠA KOVAČEVIĆ, Jalžabet - Bistričak: u susret novim istraživanjima, Prilozi Instituta za arheologiju u Zagrebu, 31 (1) (2014.), 231-238.

BRANKA VIKIĆ-BELANČIĆ, Istraživanja u Jalžabetu kao prilog upoznavanju života u zaleđu dravskog limesa, Vjesnik Arheološkog muzeja u Zagrebu, vol. 3, br. 1 (1968.), 75-102.
KSENIJA VINSKI-GASPARINI, Iskopavanje kneževskog tumulusa kod Martijanca u Podravini, Vjesnik Arheološkog muzeja u Zagrebu, ser. 3, vol. 2, br. 1 (1961.), 39-66.

KSENIJA VINSKI-GASPARINI, Osvrt na istraživanja kasnog brončanog i starijeg željeznog doba u sjevernoj Hrvatskoj, Izdanja Hrvatskog arheološkog društva, 2, Arheološka istraživanja u sjeverozapadnoj Hrvatskoj, Znanstveni skup Varaždin 22. - 25. 10. 1975., 1978., 129-146.

KSENIJA VINSKI-GASPARINI, Prethistorija ludbreškog kraja, Ludbreg, (ur.) Vlado Mađerić, Zagreb, 1984., 39-48.

KSENIJA VINSKI-GASPARINI, Grupa Martijanec - Kaptol, Praistorija jugoslavenskih zemalja, V, Željezno doba, (ur.) Alojz Benac, Ljubljana, 1987., 182-232.

BIBA TERŽAN, Starejša železna doba na slovenskem Štajerskem / The Early Iron Age in Slovenian Styria, Catalogi et monographiae, 25, Ljubljana, 1990.

BIBA TERŽAN, Auswirkungen des skythisch geprägtem Kulturkreises auf die hallstattzeitlichen Kulturgruppen Pannoniens und des Ostalpenraumes, Das Karpatenbecken und die osteuropäische Steppe: Nomadenbewegungen und Kulturaustausch in den vorchristlichen Metallzeiten (4000-500 v.Chr.), (ur.) Bernhard Hänsel i Jan Machnik, Südosteuropa-Schriften, 20, Prähistorische Archäologie in Südosteuropa, 12. München, 1998., 511-560.

BIBA TERŽAN, Štajersko-panonska halštatska skupina. Uvodnik in kratek oris, Arheološki vestnik, 70 (2019.), 319-334.

SUSANNE TIEFENGRABER, GEORG TIEFENGRABER, Landscape studies of the micro-region Strettweg (Aichfeld/Murboden) in Austrian Styria in the framework of the Iron-Age-Danube project. Man and his landscape in the Iron Age - natural environment, resources (agriculture, woods, ore), Early Iron Age Landscapes of the Danube Region, (ur.) Marko Mele i Matija Črešnar, Budapest - Graz, 2019., 75-108.

ZDENKO VINSKI, KSENIJA VINSKI-GASPARINI, O utjecajima istočnoalpske halštatske kulture i balkanske ilirske kulture na slavonskosrijemsko Podunavlje, Radovi i rasprave JAZU, II (1962.), 263-293. MAŠA VUKOVIĆ BIRUŠ, MIHAEL GOLUBIĆ, Konzerviranje i restauriranje arheoloških nalaza, Stari grad Barilović - deset godina arheoloških istraživanja, (ur.) Ana Azinović Bebek i Marijana Krmpotić, Zagreb, 2014., 105-109.

\section{Summary}

Saša Kovačević, Mihael Golubić

\section{RESTORATION OF FINDS FROM THE HALLSTATT PERIOD FOUND IN A BURIAL MOUND IN JALŽABET}

One of the most important landscapes for the Early Iron Age in the Republic of Croatia is located in Jalžabet, southeast of Varaždin (northern Croatia). The Bistričak stream flows through the slightly undulating lowland area, dominated by Gomila, one of the largest burial mounds in this part of Europe. The first archaeological field survey was done in the 1960s. In 1989, during one trial excavation of
Jalžabet and its surroundings, a team from the Varaždin City Museum located a previously unknown tomb: tumulus 2. The research in Jalžabet intensified during the implementation of the project "Monumentalized Early Iron Age landscapes in the Danube river basin" ("IronAge-Danube” Interreg DTP 2017-2019) and protective archaeological excavations of the large burial mound of 
Gomila between 2017 and 2019. Complex research on this giant tumulus, severely damaged when it was robbed, was funded by the Ministry of Culture of the Republic of Croatia, and, at the time of writing of this text, has not been fully completed.

Movable archaeological finds, and especially monumental tomb architecture with a complex funeral ritual, confirm that the Gomila burial mound is one of the most significant prehistoric monuments of this type in Europe that has been explored in recent times. The finds from tumulus 1 (Gomila) and tumulus 2 are chronologically and culturally related, and the bronze pieces from the riding equipment are practically identical. By relative chronology, they belong to the Ha D1 period, approximately to the first half of the $6^{\text {th }}$ century BC, the final phase of the Martijanec-Kaptol group or the Styria III period. Before a detailed restoration and analysis of movable finds, we can assume that Gomila belongs to the same time period as the renowned Ha D tumuli of Kleinklein, Strettweg and Kaptol.

New interdisciplinary and archaeological research was carried out at the same time as the material from the old research was processed. Bone and metal finds from tumulus 2 were restored at the Department for Conservation of Archaeological Finds (Croatian Conservation Institute) with funds provided by the Ministry of Culture of the Republic of Croatia. Conservation and restoration of new finds from the past three years was carried out at the same time. Most finds from tumulus 2 are elements of a complex scaly armour made of bronze and iron plates, connected by rivets. The numbers regarding the scope and complexity of conservation and restoration carried out on the finds from tumulus 2 speak for themselves. There were 86 bags and boxes with a total of 2281 items - 1692 of bronze and 589 of iron. Problems relating to inappropriate packaging, as well as previous attempts at restoration, were noticed during the preliminary inspection of the condition of items from tumulus 2 . Iron finds from tumulus 2 were in poor condition, because they had not gone through the desalination process. The condition of the items as received required a complex process to detect and remove old interventions, as well as the use of modern methods of preserving materials in order to save the items from further deterioration. Most metal objects were exposed to fire during the funeral ritual, and many that were made of copper alloy turned into amorphous lumps of metal, but the temperature was not high enough to melt iron. Items made of iron were desalinated in a sulphite bath for 6 months, and corrosive deposits were removed using micro-grinding and sandblasting. Most items made of copper alloy were not structurally sound, and showed signs of active corrosion. Therefore, after cleaning, they were treated with the copper-corrosion blocker Benzo-triazole. The corrosive layer was mechanically removed, and only the original surface remained. Araldite 2020 epoxy with powder pigment filler was used for gluing, consolidating and filling the holes. The surface of the metal was coated with Cosmoloid H80 wax, which protects against the effects of moisture and during further handling. The decorated arrow heads made out of bone, or antlers, were not damaged by the fire. PVA glue had been used during previous restoration interventions, and it was successfully removed with $95 \%$ ethyl alcohol. Paraloid B72 varnish of various densities was used for consolidation and gluing. The holes and cracks were filled with epoxy, with the addition of talc and small amounts of brown pigment to make the surface resemble the colour of bone.

During the excavation of tumulus 2, archaeologists were trying to research, document and then restore archaeological finds as best they could. Unfortunately, the excavations of both burial mounds in Jalžabet took place after the monuments had been severely damaged, and their main purpose was to protect and research the site, which again speaks about the need for more thoughtful protection of very sensitive prehistoric finds, sites and landscapes in Croatia and the rest of Europe. Due to the specific circumstances of the funeral ritual, and various natural and anthropogenic influences on the finds over the past millennia, the interpretation of the finds from the burial mounds in Jalžabet is very complex. Restoration of the finds, and a detailed analysis of the context, archaeological layers and structures, will help us understand what actually happened in Jalžabet more than 2,500 years ago. Various experts who are already involved in the restoration and analysis of archaeological finds and samples will play a key role in this. Archaeological excavations, accompanied by conservation and restoration, continue at the Gomila burial mound and in the entire Early Iron Age landscape of Jalžabet.

KEYwords: Jalžabet, Podravina, Central Croatia, Early Iron Age, Hallstatt period, princely graves, movable archaeological finds, conservation, restoration 